\title{
SING A INTEGRATED MCDM MODEL FOR MINING METHOD SELECTION IN PRESENCE OF UNCERTAINTY
}

\author{
Abdolreza Yazdani-Chamzini ${ }^{1}$ \\ By Siamak Haji Yakchali ${ }^{2}$ \\ Edmundas Kazimieras Zavadskas ${ }^{3}$
}

The aim objective of this study is to model mining method selection problem for a real world case in Angouran mine which is one of the major zinc producers in Iran. According to many problems of ore body extraction are direct or indirect depend on underground mining method, this issue is one of the most critical decisions in the design stage of mine that should be made. A number of the evaluation criteria that often are in conflicting with each other exist for evaluating feasible mining methods. Therefore, the problem of mining method selection is a multi-criteria decision making (MCDM) issue.

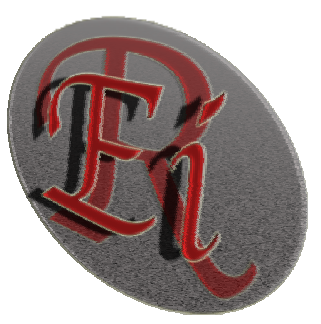

\section{Keywords: \\ Mining method selection}

MCDM

FTOPSIS

FAHP

Group decisionmaking
On the other hand, according to the sophisticated structure of the problem, imprecise data,less of information, and inherent uncertainty, the usage of the fuzzy sets can be useful. In this paper an integrated model based on fuzzy analytic hierarchy process (FAHP) and fuzzy technique for order preference by similarity to ideal solution (FTOPSIS) is developed. FAHP is applied to determine the relative weights of the evaluation criteria for mining method selection that these weights are inserted to the FTOPSIS technique to rank the alternatives and select the most appropriate alternative. The study was followed by the sensitivity analysis of the results. The results of this study demonstrate the efficiency, capability, and robustness of the proposed model, which can be applied to different types of sophisticated problems in realitv

IEL:

$\mathrm{C} 02, \mathrm{C} 44$

C54, D81

M11, M20

$\mathrm{L} 16, \mathrm{~L} 72$

P11, P41

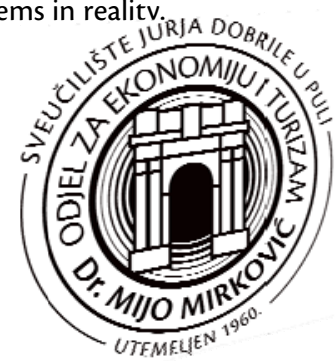

'Young Researchers Club, South Tehran Branch, Islamic Azad University, Tehran, Iran; ${ }^{2}$ Assisstance professor of Tehran University, Department of Industrial Engineering, College of Engineering, University of Tehran, Tehran, Iran; ${ }^{3}$ Vilnius Gediminas Technical University, Faculty of Civil Engineering, Sauletekio al. 11, LT-10223 Vilnius, Lithuania 


\section{INTRODUCTION}

Mining, one of the most important activities, is applied in order to extract mineral resources from the earth. This activity has played a much more significant role in the development of civilization (Hartman, 1992). Mining is divided into two main parts, including surface and underground mining. The former is called when the process of mineral extraction is carried out by removing the overburden. The latter is termed when all extractions are accomplished beneath the earth's surface.Both surface and underground mining are fallen into different mining methods.

Underground mining method selection is one of the most critical decisions in the design stage of mine that should be made. Because the ground control on the mining areas, planning the ventilation system, decreasing the maintenance costs of gallery, developing new mining panels and preparing the underground production schedule are also directly related to underground mining method selection, such like geology of deposit (Alpay, Yavuz, 2007, 2009).These issues indicate the importance and complication of mining method selection in mining projects.

This selection is a complex and sophisticated decision making problem because various qualitative and quantitative criteria may affect the decision. Increasing the number of criteria in decision making process makes the decision problem more complex, but the rightness of the decision also increases (Alpay, Yavuz, 2009). According to the complexity of the decision process, many traditional methods take into account only limited number of criteriaand in these methods, the problem is analyzed from quantitative viewpoint (Boshkov, Wright, 1973;Morrison, 1976;Laubscher, 1981;Nicholas,1981; Hartman, 1987; Miller-Tait et al. 1995). Therefore, it is a need to use the methods that are able to take into account all effective criteria.

The merit of using multi-criteria decision making (MCDM) methods is their ability to solve complex and multi criteria problems by handling both quantitative and qualitative criteria. The MCDM methods arestrong tools for determining the best alternative among a pool of the feasible alternatives in mining method selection (Table 1). 
TABLE 1. MCDM METHODS USED IN MINING METHOD SELECTION

\begin{tabular}{|c|c|c|}
\hline Reference & Method & Considered problem \\
\hline Leeneer, Pastijn, 2002 & PROMETHEE & Selecting land mine detection strategies \\
\hline Namin,et al., 2009 & AHP- PROMETHEE & $\begin{array}{l}\text { Selecting of suitable mining method } \\
\text { selection }\end{array}$ \\
\hline Alpay, Yavuz, 2007 & AHP & Underground mining method selection \\
\hline Alpay, Yavuz, 2009 & $\mathrm{AHP}$ & Underground mining method selection \\
\hline Musingwini, 2010 & AHP & $\begin{array}{l}\text { Techno-Economic Optimization of Level and } \\
\text { Raise }\end{array}$ \\
\hline $\begin{array}{l}\text { Owusu-Mensah, } \\
\text { Musingwini, } 2011\end{array}$ & $\mathrm{AHP}$ & Evaluation of ore transport \\
\hline Bazzaz,et al. 2009 & AHP-TOPSIS & $\begin{array}{l}\text { Optimal Open Pit Mining Equipment } \\
\text { Selection }\end{array}$ \\
\hline Bazzaz,et al. 2011 & FAHP & Open pit mines equipment selection \\
\hline Azadeh,et al. 2010 & FAHP & Mining method selection \\
\hline Bangian,et al. 2011 & FAHP & Post mining land use for pit area \\
\hline Naghadehi,et al. 2009 & FAHP & $\begin{array}{l}\text { Selection of Optimum Underground Mining } \\
\text { Method }\end{array}$ \\
\hline Mikaeil, et al. 2009 & FAHP & $\begin{array}{l}\text { Selection of the Optimum Underground } \\
\text { Mining Method }\end{array}$ \\
\hline Fouladgar, et al. 2012 & AHP-Fuzzy COPRAS & Maintenance strategy selection \\
\hline Lashgari, et al. 2011 & FAHP-FTOPSIS & Model for shaft sinking method selection \\
\hline Lashgari, et al. 2012 & AHP-ANP-TOPSIS & Equipment selection \\
\hline Namin, et al. 2008 & FTOPSIS & Mining method selection of mineral deposit \\
\hline Bazzaz,et al. 2008 & FTOPSIS & $\begin{array}{l}\text { Loading-haulage equipment selection in } \\
\text { open pit mines }\end{array}$ \\
\hline $\begin{array}{l}\text { Yazdani-Chamzini, } \\
\text { Yakhchali, 2012a }\end{array}$ & FTOPSIS-AHP & $\begin{array}{l}\text { Handling equipment Selection in open pit } \\
\text { mines }\end{array}$ \\
\hline $\begin{array}{l}\text { Yazdani-Chamzini, } \\
\text { Yakhchali, 2012b }\end{array}$ & FAHP-FTOPSIS & Evaluation of tunneling projects \\
\hline Azimi,et al. 2011 & SWOT-ANP-VIKOR & Evaluating the strategies of the mining sector \\
\hline
\end{tabular}

Source: Author's calculation

Technique for Order Preference by Similarity to Ideal Solution (TOPSIS) is one common MCDM method that takes into consider the ideal and the anti-ideal solutions simultaneously. This technique is applied by different researches because of being rational, simple computations, and results are obtained in shorter time than other methods such as AHP (analytical hierarchy process) and ANP (analytic network process) (Fouladgar,etal. 2011; Lashgari,etal. 2011). 
According to the inherent complexity and uncertainty associated with real world problems as well as the vagueness of human feeling, it is difficult for decision makers to express their opinions with precise numerical values for the criteria and alternatives. However, TOPSIS is often criticized for its inability to deal with vague and uncertain problems (Yu,et al. 2011), so that; without considering the inherent uncertainty, the results may be unrealistic and unreliable.

On the other hand, fuzzy logic is a powerful mathematical tool that is capable to handle the existing uncertainty. Therefore, TOPSIS is combined with fuzzy logic in order to eliminate the drawbacks of the conventional TOPSIS, which is well-known asFTOPSIS. This technique has been adopted in many different applications, includingservice quality (Büyüközkan, Çifçi, 2012; Awasthi,et al. 2011a), strategic management (Ding, 2005; Kahraman, 2004; Kabak, 2012; Fu, 2007; Dağdeviren, 2009; Paksoy,et al. 2011; Fouladgar,et al. 2011), risk assessment (Braglia,et al. 2003; Wang, Elhag, 2006; KarimiAzari et al. 2011; Fouladgar, et al. 2012), supply chain management (Chen, etal. 2006), location selection (Yong, 2006; Anagnostopoulos et al. 2008; Montazeri, 2011), service quality (Tseng, 2011; Önüt, 2010), transportation system (Awasthi et al. 2011b; Zandi, Tavana, 2011) and in mining method selection (Lashgari, et al. 2011; Namin, et al. 2008; Bezzazi, et al. 2008; Fouladgar, et al. 2012; Yazdani-Chamzini, Yakhchali, 2012 a,b).

It is clear that this technique has demonstrated its capability and effectiveness as a practical engineering and problem-solving tool.

On the other hand, AHP (analytical hierarchy process) is widely used to calculate the weights of evaluation criteria. This method use pair-wise comparison for obtaining the relative weights of criteria. AHP is strongly connected to human judgment and pairwise comparisons in AHP may cause evaluator's assessment bias which makes the comparison judgment matrix inconsistent (Aydogan, 2011). Therefore, fuzzy analytical hierarchy process (FAHP) is employed to solve the bias problem in AHP. AFAHP method used in mining method selection (Bezzazi, et al. 2011; Azadech, et al. 2010; Bagdian, et al. 2011; Naghadehi,et al. 2009; Mikaeil,et al. 2009). FAHP method with FTOPSIS method used in different applications (Torfi,et al. 2010; Chen, Yang, 2011; Rostamzadeh,et al. 2011; Ic, Yurdakui, 2009; Zouggari, Benyoucef, 2012; Kung,et al. 2011; YazdaniChamzini, Yakhchali, 2012 a,b; Lashgari, et al. 2011).

The main aim of this paper is to develop an integrated model based on FAHP and FTOPSIS methods in order to evaluatemining methodsand select the best alternative inthe Anguran mine.FTOPSIS is employed to select a mining method and the FAHP isapplied to calculate criteria weights.

The rest of this paper is organized as follows. In section 2, a brief review of fuzzy theory is presented, including fuzzy sets, fuzzy numbers, and linguistic variables.Section 3 illustrates the FAHP methodology for calculating the relative weights of evaluation criteria. The procedure of the Fuzzy TOPSIS method is describedin section 4. The proposed model is presented in section 5 . Section 6 presents an empirical study of mining method selection. A sensitivity analysis is conducted in section 7. Finally, concluding remarks are discussed in section 8.

\section{FUZZY THEORY}

Complexity is an important part of most real world decision problems that is due to the existing uncertainty, imprecise knowledge, and less of information. The use of the techniques and tools that allow the available information to be used with the adequate guaranty is desired fordealing with such complexity. Fuzzy logic, introduced by Zadeh (1965), is a powerful tool for facing with this type of problems. Fuzzy numbers may be of almost any shape (though conventionallythey 
are required to be convex and to have finite area), but frequently they will be triangular (piecewise linear), s-shape (piecewise quadratic) or normal (bell shaped) (Kelemenis etal. 2011).

A triangular fuzzy number (TFN) is defined as $\tilde{A}=(a, b, c)$; which $a, b$, and $c$ are crisp numbers and $a \leq b \leq c$.

A fuzzy number is defined by its membership function whose values can be any number in the interval $[0,1]$. Assume that TFNs start rising from zero at $x=a$; reach a maximum of 1 at $x=b$; and decline to zero at $x=c$ as shown in Fig. 1.Then the membership function $\mu_{\tilde{A}}(x)$ of a TFN is given by

$\mu_{\tilde{A}}(x)= \begin{cases}0, & x<a \\ (x-a) /(b-a), & a \leq x<b \\ (x-c) /(b-c), & b \leq x<c \\ 0, & x>c\end{cases}$

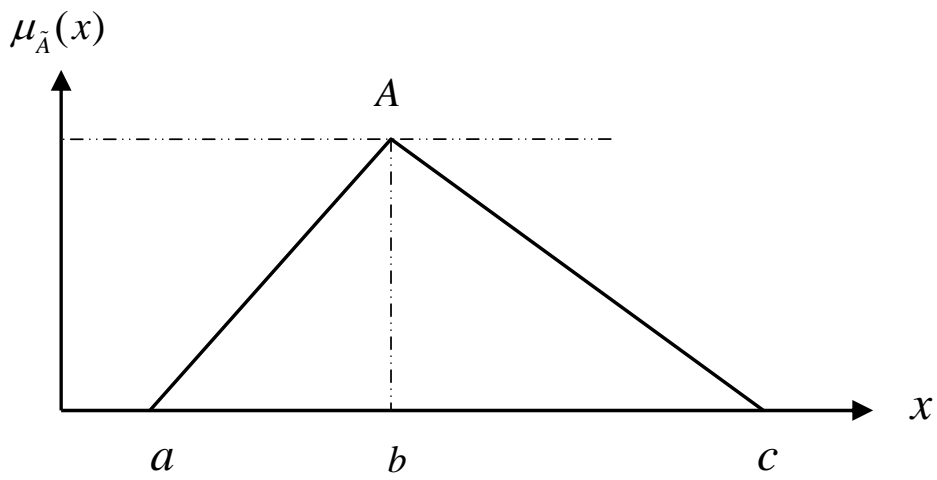

FIGURE .1. TRIANGULAR FUZZY NUMBER

Source: Author's calculation

Let $\tilde{a}=\left(a_{1}, b_{1}, c_{1}\right)$ and $\tilde{b}=\left(a_{2}, b_{2}, c_{2}\right)$ be two TFNs then the vertex method is defined to compute the distance between them by Eq. (2):

$d(\tilde{a}, \tilde{b})=\sqrt{\frac{1}{3}\left[\left(a_{1}-a_{2}\right)^{2}+\left(b_{1}-b_{2}\right)^{2}+\left(c_{1}-c_{2}\right)^{2}\right]}$ 


\section{FUZZY AHP}

Analytical hierarchy process (AHP), proposed by Saaty (1980),is a popular MCDM method that decomposes a sophisticated problem into ahierarchy. The elements of hierarchy levels are compared in pairs to assess their relative preference with respect to each of the elements at the next higher level(Singh \& Benyoucef, 2011). The AHP is widely employed for tackling multicriteria decision making problems in real world applications. However, in many practical cases the human preference model is uncertain and evaluator might be reluctant or unable to assign crisp values tothe comparison judgments (Chan \& Kumar, 2007). The merit of using a fuzzy approach is to determine the relative importance of attributes using fuzzy numbers instead of precise numbers (Önüt, Soner, 2008; Sun, Lin, 2009; Sun, 2010; Kara, 2011).There are many fuzzy AHP methods proposed on the basis of the concepts of the fuzzy set theory and hierarchical structure by various researchers to solve the selection problems in different fields of application (Van Laarhoven and Pedrycz, 1983; Buckley, 1985;Boender et al. 1989; Chang, 1996;Cheng, 1996).

In this study, we use Chang's extent analysis method (Chang, 1996) due to its computational simplicity and effectiveness. This method utilizes TFNs for pairwise comparison matrices. Modeling using TFNs has demonstrated to be a successful way for formulating decision making problems where the information available is subjective and imprecise (Dağdeviren \& Yüksel, 2008).

Let $X=\left\{x_{1}, x_{2}, \ldots, x_{n}\right\}$ be an object set and $U=\left\{u_{1}, u_{2}, \ldots, u_{m}\right\}$ be a goal set. According to the method of Chang's extent analysis, each object is taken and extent analysis for each goal, gi, is performed, respectively. Therefore, $m$ extent analysis values for each object can be obtained, with the following signs: $M_{g i}^{1}, M_{g i}^{2}, \ldots, M_{g i}^{m}, i=1,2, \ldots, n$. Where all the $M_{g i}^{j}(j=1,2, \ldots, m)$ are TFNs.

The procedure of Chang's extent analysis is defined in the following steps:

Step 1- The value of fuzzy synthetic extent with respect to ith object is calculated as:

$S_{i}=\sum_{j=1}^{m} M_{g i}^{j} \otimes\left[\sum_{i=1}^{n} \sum_{j=1}^{m} M_{g i}^{j}\right]^{-1}$

To obtain $\sum_{j=i}^{m} M_{g i}^{j}$, perform the fuzzy addition operation of $m$ extent analysis values for a particular matrix such that

$$
\sum_{j=1}^{m} M_{g i}^{j}=\left(\sum_{j=1}^{m} l_{i}, \sum_{j=1}^{m} m_{i}, \sum_{j=1}^{m} u_{i}\right)
$$

And to obtain $\left[\sum_{i=1}^{n} \sum_{j=1}^{m} M_{g i}^{j}\right]^{-1}$, perform the fuzzy addition operation of $M_{g i}^{j}(j=1,2, \ldots, m)$ values such that 
$\sum_{i=1}^{n} \sum_{j=1}^{m} M_{g i}^{j}=\left(\sum_{i=1}^{n} l_{i}, \sum_{i=1}^{n} m_{i}, \sum_{i=1}^{n} u_{i}\right)$

And then calculate the inverse of the vector in Eq. (6) such that

$$
\left[\sum_{n=1}^{n} \sum_{j=1}^{m} M_{g i}^{j}\right]^{-1}=\left(\frac{1}{\sum_{i=1}^{n} u_{i}}, \frac{1}{\sum_{i=1}^{n} m_{i}}, \frac{1}{\sum_{i=1}^{n} l_{i}}\right)
$$

Step 2- The degree of possibility of $M_{2}=\left(l_{2}, m_{2}, u_{2}\right) \geq M_{1}=\left(l_{1}, m_{1}, u_{1}\right)$ is assigned as

$$
V\left(M_{2} \geq M_{1}\right)=\sup _{y \geq x}\left[\min \left(\mu_{M 1}(x), \mu_{M 2}(y)\right)\right]
$$

And can be equivalently expressed as follows:

$$
V\left(M_{2} \geq M_{1}\right)=h g t\left(M_{1} \cap M_{2}\right)=\mu_{M 2}(d)= \begin{cases}1, & \text { if } m_{2} \geq m_{1} \\ 0, & \text { if } l_{1} \geq u_{2} \\ \frac{l_{1}-u_{2}}{\left(m_{2}-u_{2}\right)-\left(m_{1}-l_{1}\right)}, & \text { otherwise }\end{cases}
$$

Both the values of $V\left(M_{1} \geq M_{2}\right)$ and $V\left(M_{2} \geq M_{1}\right)$ are needed to compare $M_{1}$ and $M_{2}$.

Step 3- The degree of possibility for a convex fuzzy number to be greater than $k$ convex fuzzy numbers $M_{i}(i=1,2, \ldots, k)$ can be computed by

$V\left(M \geq M_{1}, M_{2}, \ldots, M_{k}\right)=V\left[\left(M \geq M_{1}\right)\right.$ and $\left(M \geq M_{2}\right)$ and $\ldots$ and $\left.\left(M \geq M_{k}\right)\right]$

$=\min V\left(M \geq M_{i}\right), \quad \mathrm{i}=1,2, \ldots, \mathrm{k}$

Assume that

$d^{\prime}\left(A_{i}\right)=\min V\left(S_{i} \geq S_{k}\right)$

For $k=1,2, \ldots, n ; k \neq i$.

Then the weight vector is obtained by

$W^{\prime}=\left(d^{\prime}\left(A_{1}\right), d^{\prime}\left(A_{2}\right), \ldots, d^{\prime}\left(A_{n}\right)\right)^{T}$ 
Where $A_{i}(i=1,2, \ldots, n)$ are $n$ elements.

Step 4- The normalized weight vectors are resulted through normalization

$W=\left(d\left(A_{1}\right), d\left(A_{2}\right), \ldots, d\left(A_{n}\right)\right)^{T}$

Where $W$ is a non-fuzzy number.

\section{FUZZY TOPSIS}

The Technique for Order Preference by Similarity to Ideal Solution (TOPSIS) was first introduced by Hwang and Yoon (1981).TOPSIS method is based on the concept that the most appropriate alternative shouldhave the shortest distance from the positive ideal solution (PIS)and the farthest distance from the negative ideal solution (NIS). PIS minimizes the cost criteria and maximizes the benefit criteria, whereas the NIS minimizes the benefit criteria and maximizes the cost criteria (Kelemenis et al. 2011). There have been plenty of studies related with the TOPSIS method in the literature (Parkan \& Wu, 1999; Gamberini et al. 2006; Yu et al. 2009; Chen et al. 2009; Antuchevičieneet al. 2010, 2011; Tupenaite et al. 2010; Chang et al. 2010). In the TOPSIS method, decision makers' judgments are represented with crisp values. According to the problems associated with determining the precise preference rating to an alternative for the criteria under consideration, decision makers are keen onusing fuzzy numbers instead of precise numbers. For this reason, the fuzzy TOPSIS method is appropriate for solving real world problems under a fuzzy environment (Li, 2007; Chen \& Tsao, 2008; Ashtiani et al. 2009; Wang et al. 2009; Torfi et al. 2010; Chen \& Hung, 2010; Tupenaite et al. 2010; Han\&Liu, 2011; Aydogan, 2011; Huang \& Peng, 2011; Fouladgar et al. 2011; Chen, 2011; Sadi-Nezhad, Damghani, 2011; Kutlu \& Ekmekçioğlu, 2012; Awasthi \& Chauhan, 2012). The major steps of the FTOPSIS can be described as follows:

Step 1. Choose the linguistic variablesfor the alternatives with respect to the evaluation criteria.The linguistic variables are linguistic terms that express the values by words or sentences. Each linguistic value can be representedby a TFN which can be assigned to amembership function. In this study, we employed TFNs be associated to the linguistic values and scales of five points for the ratings of alternatives (Table 2 and Fig. 2) and ten points for importance weights of the evaluation criteria (Table 3 and Fig. 3). 
TABLE 2. LINGUISTIC VARIABLES FOR EACH CRITERION

\begin{tabular}{ll}
\hline \hline Linguistic variables & Triangular fuzzy number \\
\hline Equally preferred (EP) & $(1,1,2)$ \\
Equally to moderately (EM) & $(1,2,3)$ \\
Moderately preferred (MP) & $(2,3,4)$ \\
Moderately to strongly (MS) & $(3,4,5)$ \\
Strongly preferred (SP) & $(4,5,6)$ \\
Strongly to very strongly (SVS) & $(5,6,7)$ \\
Very strongly preferred (VSP) & $(6,7,8)$ \\
Very strongly to extremely (VSE) & $(7,8,9)$ \\
Extremely preferred (EXP) & $(8,9,10)$ \\
Definitely preferred (DP) & $(9,10,10)$ \\
\hline \hline
\end{tabular}

Source: Author's calculation

TABLE 3. LINGUISTIC VARIABLES FOR THE RATING OF ALTERNATIVES

\begin{tabular}{ll}
\hline \hline Linguistic variables & Triangular fuzzy number \\
\hline Very poor (VP) & $(0,0.15,0.3)$ \\
Poor (P) & $(0.2,0.35,0.5)$ \\
Fair (F) & $(0.4,0.5,0.6)$ \\
Good (G) & $(0.5,0.65,0.8)$ \\
Very good (VG) & $(0.7,0.85,1)$ \\
\hline \hline
\end{tabular}

Source: Author's calculation

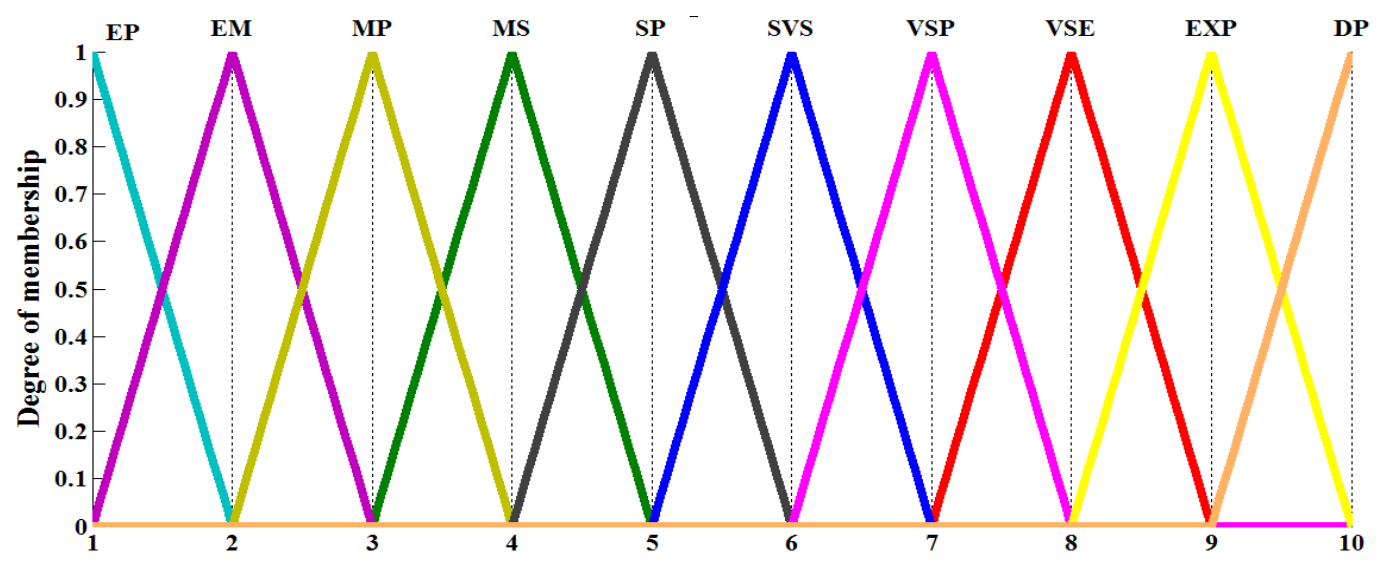

Fig. 2. Membership function of linguistic variables for importance weight

Source: Author's calculation 


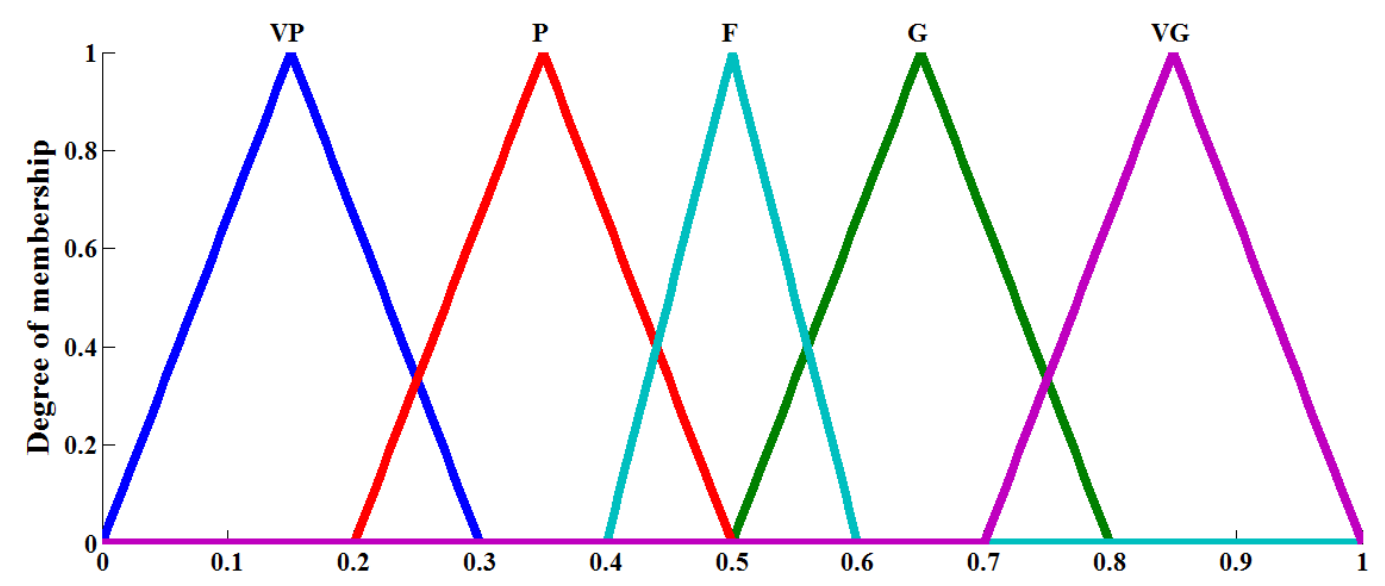

Fig. 3. Membership function of linguistic variables for preference rating

Source: Author's calculation

Step 2. Construct the fuzzy decision matrix.

To calculate the performance of a set of alternatives on a given set of criteria, the decision matrix of $m \times n$ dimension is formed, which $m$ and $n$ are the number of alternatives and criteria respectively.

Step 3. Aggregate the ratings of alternatives respect to each criterion $\left(\tilde{x}_{i j}\right)$ and fuzzy weights of evaluation criteria $\left(\tilde{w}_{j}\right)$. In order to aggregate the ratings of alternatives versus each criterion and fuzzy weight of each criterion, the arithmetic mean is applied.

Let the fuzzy ratings of all decision makers be TFNs $\tilde{X}_{i j k}=\left(a_{i j k}, b_{i j k}, c_{i j k}\right), k=1,2, \ldots, K$, which $\tilde{X}_{i j k}$ represents the value of the $i$ th alternative respect to the $j$ th criterion by $k$ th decision maker. Then the aggregated fuzzy rating can be defined as

$\tilde{X}_{i j}=\left(a_{i j}, b_{i j}, c_{i j}\right), \quad k=1,2, \ldots, K$

Where

$$
\begin{aligned}
& a_{i j}=\frac{1}{K} \sum_{k=1}^{k} a_{i j k} \\
& b_{i j}=\frac{1}{K} \sum_{k=1}^{k} b_{i j k}
\end{aligned}
$$


$c_{i j}=\frac{1}{K} \sum_{k=1}^{k} c_{i j k}$

Let the fuzzy weights of evaluation criteria be TFNs $\tilde{w}_{j k}=\left(w_{j k 1}, w_{j k 2}, w_{j k 3}\right) ; k=1,2, \ldots, k$. Then the aggregated fuzzy weight of each criterion can be calculated as

$$
w_{j}=\left(w_{j 1}, w_{j 2}, w_{j 3}\right), \quad k=1,2, \ldots, K
$$

Where

$$
\begin{aligned}
& w_{j 1}=\frac{1}{K} \sum_{k=1}^{k} w_{j k 1} \\
& w_{j 2}=\frac{1}{K} \sum_{k=1}^{k} w_{j k 2} \\
& w_{j 3}=\frac{1}{K} \sum_{k=1}^{k} w_{j k 3}
\end{aligned}
$$

Step 4. Calculate the normalized fuzzy decision matrix.

In order to transform the various criteria scales into a comparable scale, the linear scale transformation is employed. The normalized fuzzy decision matrix can be computed by $\tilde{R}$ :

$$
\tilde{R}=\left[\tilde{r}_{i j}\right]_{m \times n}
$$

and

$$
\tilde{r}_{i j}=\left(\frac{a_{i j}}{c_{j}^{*}}, \frac{b_{i j}}{c_{j}^{*}}, \frac{c_{i j}}{c_{j}^{*}}\right), c_{j}^{*}=\max _{i} c_{i j}
$$

Step 5. Calculate the weighted normalized fuzzy decision matrix.

We can compute the weighted normalized fuzzy decision matrix by considering the relative importance of evaluation criteria as

$$
\tilde{V}=\left[\tilde{V}_{i j}\right]_{m \times n}
$$

and

$$
\tilde{v}_{i j}=\tilde{r}_{i j} \times w_{j}
$$


Where $W=\left\{w_{j}: j=1,2, \ldots, n\right\}$ normalized criteria weights.

Step 6. Identify positive ideal $\left(A^{*}\right)$ and negative ideal $\left(A^{-}\right)$solutions. The fuzzy positive -ideal solution and the fuzzy negative-ideal solution are shown in Eqs. (18), (19).

$$
A^{*}=\left(\tilde{v}_{1}^{+}, \tilde{v}_{2}^{+}, \tilde{v}_{3}^{+}, \ldots, \tilde{v}_{n}^{+}\right)=\left\{\max _{i} v_{i j}(i=1,2, \ldots, n)\right\}
$$

$$
A^{-}=\left(\tilde{v}_{1}^{-}, \tilde{v}_{2}^{-}, \tilde{v}_{3}^{-}, \ldots, \tilde{v}_{n}^{-}\right)=\left\{\min _{i} v_{i j} \mid(i=1,2, \ldots, n)\right\}
$$

Step 7. Calculate separation measures. The distance of each alternative from $A^{*}$ and $A^{-}$can be currently calculated using Eqs. (20), (21).

$$
d_{i}^{+}=\sum_{j=1}^{n} d\left(\tilde{v}_{i j}, \tilde{v}_{j}^{+}\right), i=1,2, \ldots, m
$$

$$
d_{i}^{-}=\sum_{j=1}^{n} d\left(\tilde{v}_{i j}, \tilde{v}_{j}^{-}\right), i=1,2, \ldots, m
$$

Step 8. Calculate the similarities to ideal solution. This step solves the similarities to an ideal solution by Eq. (22).

$$
C C_{i}^{*}=\frac{d_{i}^{-}}{d_{i}^{-}+d_{i}^{*}}
$$

Step 9. Rank preference order. Choose an alternative with maximum $C C_{i}^{*}$ or rank alternatives according to $C C_{i}^{*}$ in descending order.

\section{THE PROPOSED MODEL}

The proposed model for evaluating the underground mining methods in Angouran mine, contained of FAHP and FTOPSIS methods, comprises of three main steps: (1) determine the main and sub evaluation criteria; (2) calculate the relative weights of criteria by FAHP and (3) evaluate the possible alternatives by FTOPSIS and finally select the optimum alternative among a pool of alternatives. Schematic diagram of the proposed model for mining method selection is depicted in Fig. 4. 


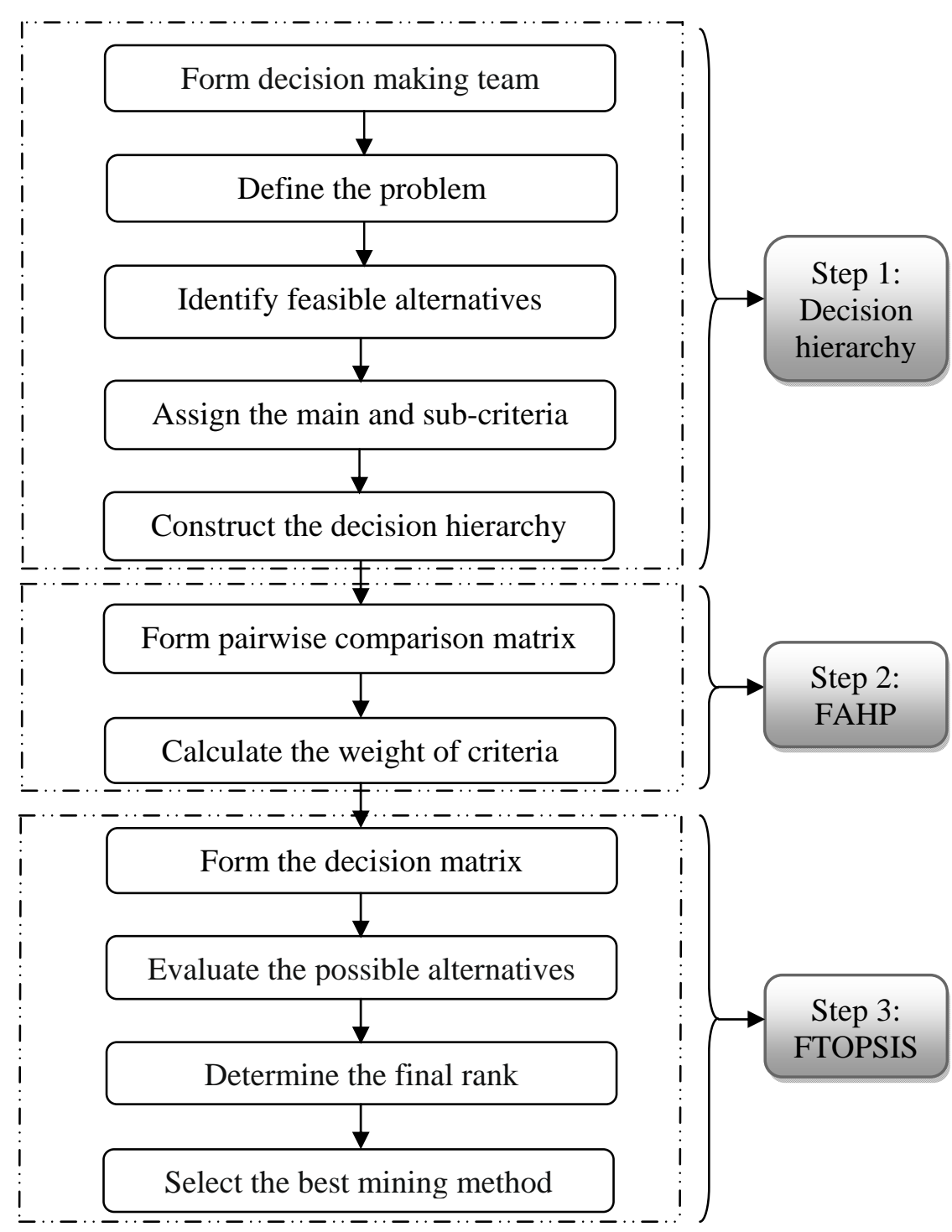

Fig. 4. Schematic diagram of the proposed model

Source: Author's calculation

In the step 1, after defining the problem, the feasible mining methods for the extraction process of the ore are identified. Next, the effective criteria of possible alternatives are determined. In the final phase of the step 1, the decision hierarchy is structured such that the goal is in the first level, evaluation criteria are in the second level, sub-criteria are in the third level, and possible alternatives are on the last level.In the step 2, after constructingthe decision hierarchy, the relative weights of the evaluation criteria are obtained by using the FAHP technique. Based on these evaluation criteria, the required data in order to form the pairwise comparison matrix are collected from expert's knowledge.In the step 3, the performance ratings of the feasible alternatives corresponding to the evaluation criteriaare assigned by applying linguistic variables. Finally, FTOPSIS is appliedto evaluate the alternativesand select the best underground mining method among a pool of alternatives. 


\section{AN EMPIRICAL APPLICATION}

The purpose of the empirical application is to illustrate the use of the suggested method. Angouran $\mathrm{Zn}-\mathrm{Pb}$ deposit is located in the western Zanjan province about $450 \mathrm{~km}$ northwest of Tehran (Fig. 5a). This deposit is one of the major zinc producers in Iran, a country with approximately 11 million tons of zinc metal constituent. Angouran has 16 million tons of ore with a zinc concentration of $26 \%$ and a lead concentration of $6 \%{ }^{4}$. This deposit is close to the Urumieh-Dokhtar Magmatic Arc, which is situated within one of a number of metamorphic inlier complexes in the central Sanandaj-Sirjan Zone of the Zagros orogenic belt (Gilg et al. 2005). A metamorphic core complex surrounds the Angouran deposit, which comprises amphibolites, serpentinites, gneisses, micaschists, and various, mainly calcitic and rarely dolomitic marbles. Some of the geological specifications of the area are represented in Fig.5b.
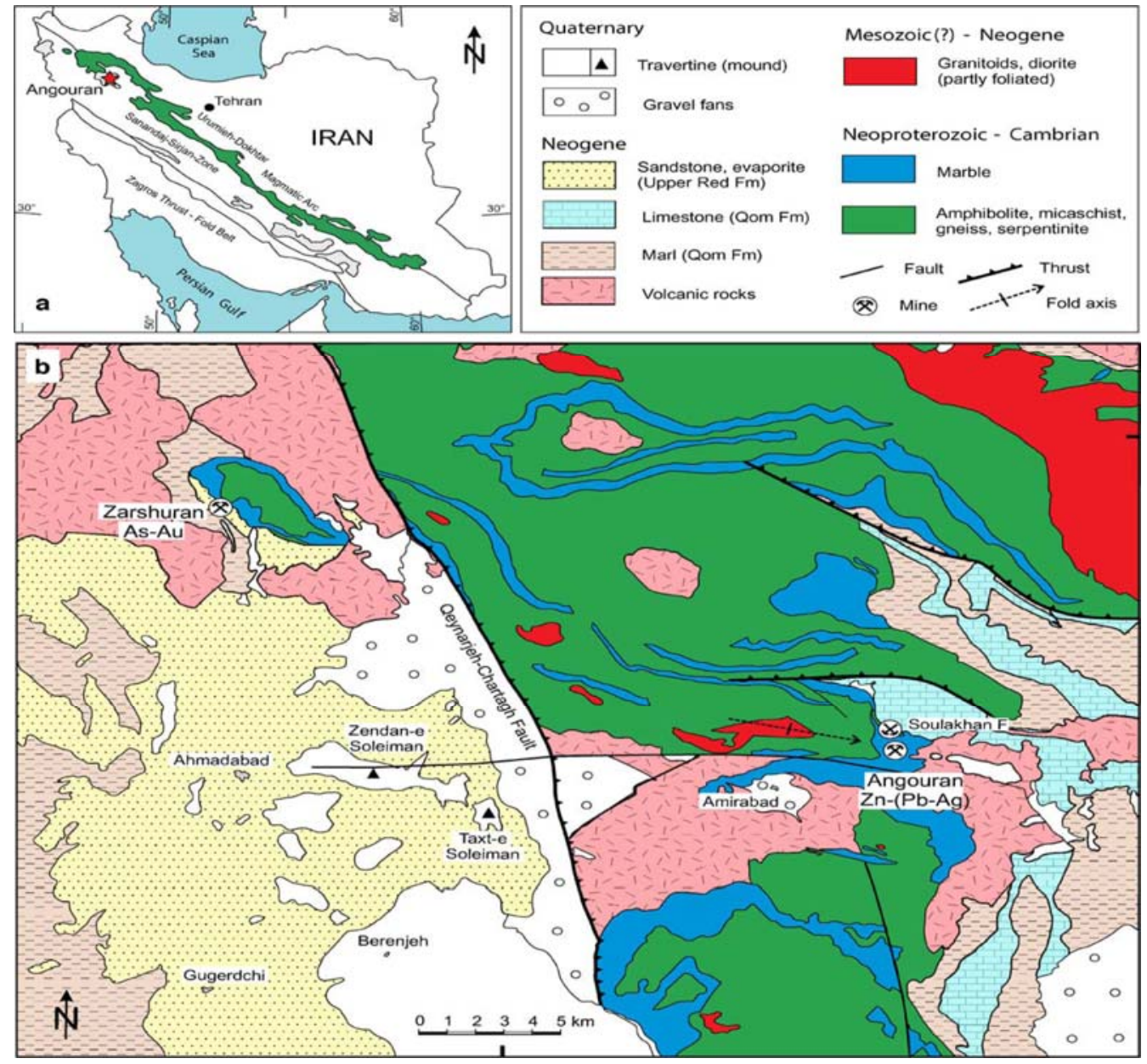

Fig. 5. Geography of Angouran mine (a) and schematic regional geological map of the area (b) (Boni et al, 2007)

Source: Author's calculation

\footnotetext{
${ }^{4}$ www.turquoisepartners.com
} 
The Angouran orebody is located in the crest of an open anticlinal structure within the metamorphic basement that plunges eastward at $10-20^{\circ}$ (Gilg et al. 2005). This orebody is some $600 \mathrm{~m}$ long in Northern-Southern line and $200-400 \mathrm{~m}$ across. The orebody is delimited by two major NNW-SSE and NW-SE trending faults and a third NE-SW fault (Boni et al. 2007).

In Angouran mine, extraction of deposit has been started from near surface by open pit mining and it has continued to the level of 2880 meters. According to increasing the extraction depth and environmental requirements, mine is designed to transfer from open pit to underground mining. For this reason, underground mining method should be selected; so that, the evaluation criteria under consideration be satisfied.

\section{A. Determine the main and sub-criteria}

Criteria should be determined that cover the requirements connected with the mining method selection problem. For instance, various criteria should be considered for health, safety, and the environment (HSE). As the focus of this study is on mining method selection, the proposed set of criteria, taken from literature review and a number of face to face interviews with experts as well as after preliminary screening, consists of ten technical parameters, nineoperational parameters, and three economical parameters that every mining method should satisfy.

The main characteristics of the technical parameters are Ore body thickness (C11), Ore body shape (C12), Ore body depth (C13), Ore body dip (C14), Footwall RMR ${ }^{5}(\mathrm{C} 15)$, Hanging wall RMR (C16), Ore body RMR (C17), Footwall RSS ${ }^{6}$ (C18), Hanging wall RSS (C19), and Ore body RSS (C110). The operational parameters to be taken into account are Safety (C21), health (C22), Environmental aspects (C23), Subsidence (C24), Dilution (C25), Flexibility (C26), Production rate (C27), Needed newtechnology (C28), and Having need of skilled labor force (C29). The economical parameters are related to Operating costs (C31), Capital costs (C32), and Reclamation costs (C33).

As a result, these twenty two criteria were employed in the process of the evaluation and decision hierarchy is established accordingly as depicted in Fig. 6.The hierarchy of mining method selection can be divided into three levels: level 1 includes the main goal of the hierarchy, which is selection the most optimum mining method. The main criteria are on the second level. The subcriteria are located in the third level. Level 4 comprises the feasible alternatives determined by the decision maker team, including Block Caving (A1), Sublevel Stoping (A2), Sublevel Caving (A3), Cut \& Fill (A4),Top Slicing (A5), and Square Set Stoping (A6).

\footnotetext{
${ }^{5}$ Rock mass rating

${ }^{6}$ Rock Substance strength
} 


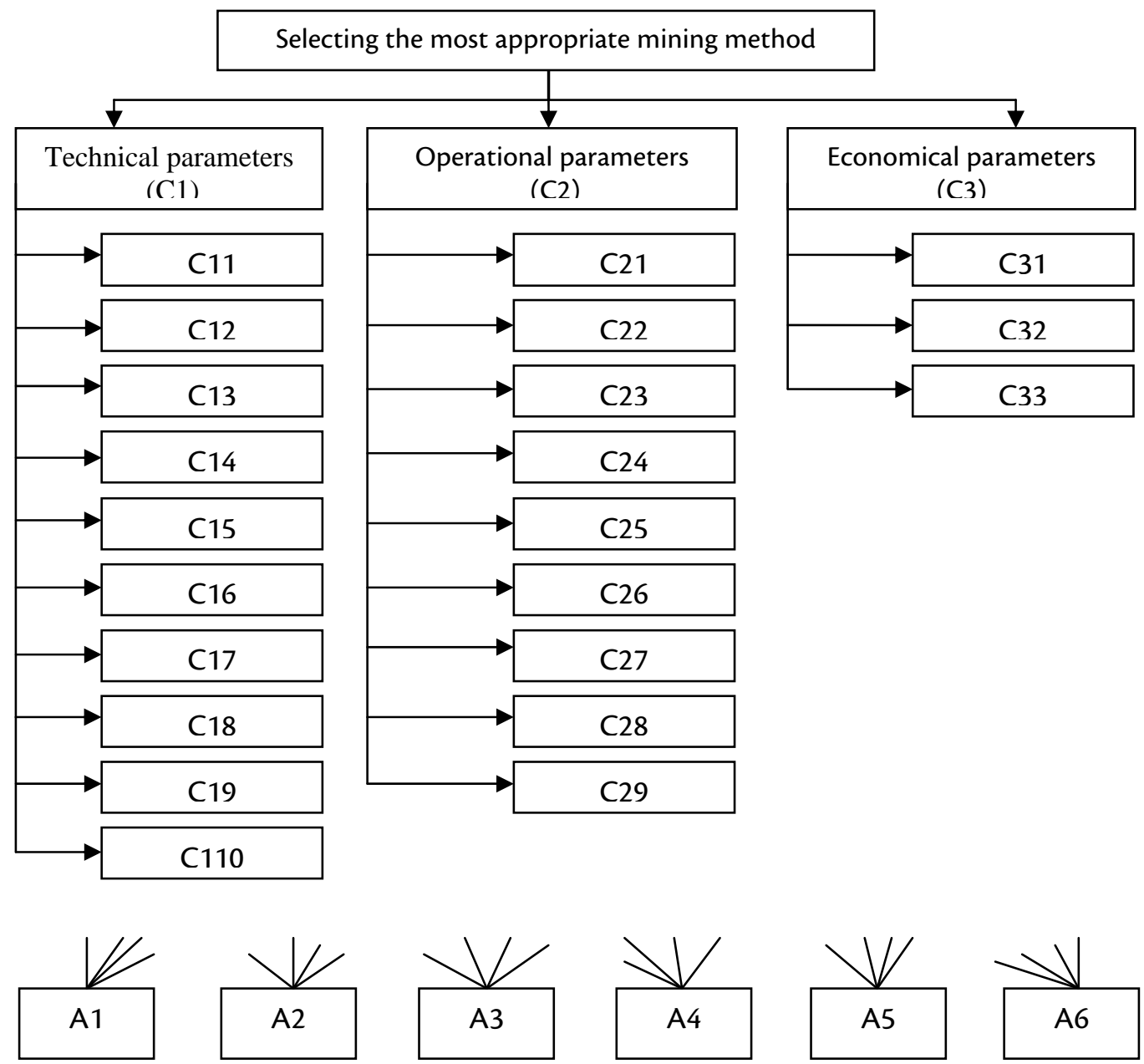

Fig. 6. Decision hierarchy

Source: Author's calculation

\section{B. Calculate the relative weights of criteria by FAHP}

After constructing the decision hierarchy for the problem, the relative weights of the main and sub-criteria to be utilized in evaluation process are calculated by using the FAHP method. Group decision is used in assigning the relative importance of the evaluation criteria, as well as in the next steps of this study. An aggregation method is employed to combine expert's judgments. In this step, the fifteendecision makers with a high level of experience in the field of mining design are given the task of constructing individual pairwise comparison matrix by using the scale presented in Fig. 2 and Table 1. Arithmetic means of these values are calculated by using Eq. (13) to obtain the overall pairwise comparison matrixon which there is a consensus. For instance, when comparing the safety $(C 21)$ and health $(C 22)$ criteria, the responses of fifteen experts are $E M, M P, M P, E M, M P, M S, M P, E M, M S, M S, E M, E M, S P, E M$ and EM, respectively. The results derived from the computations according to the final fuzzy matrices provided in Tables (4), (5), (6), and (7), are presented in Tables(8), (9), (10), and (11), respectively.The weight calculation details by using FAHP are given below. 
TABLE 4. FINAL PAIRWISE COMPARISON MATRIX OF TECHNICAL PARAMETERS

\begin{tabular}{|c|c|c|c|c|c|c|c|c|c|c|}
\hline & C11 & $\mathrm{C} 12$ & $\mathrm{C} 13$ & $\mathrm{C} 14$ & $\mathrm{C} 15$ & $\mathrm{C} 16$ & $\mathrm{C} 17$ & $\mathrm{C} 18$ & C19 & C110 \\
\hline \multirow[t]{3}{*}{ C11 } & 1.00 & 0.56 & 1.32 & 0.51 & 1.79 & 1.03 & 0.64 & 1.47 & 1.35 & 0.56 \\
\hline & 1.00 & 0.90 & 2.70 & 0.83 & 3.70 & 1.85 & 0.89 & 3.45 & 2.94 & 0.93 \\
\hline & 1.00 & 1.35 & 4.17 & 1.92 & 5.26 & 2.78 & 1.33 & 5.88 & 4.76 & 1.61 \\
\hline \multirow[t]{3}{*}{$\mathrm{C} 12$} & 0.74 & 1.00 & 2.44 & 0.54 & 2.63 & 1.72 & 1.12 & 2.70 & 1.79 & 1.20 \\
\hline & 1.11 & 1.00 & 4.35 & 0.85 & 3.45 & 2.56 & 1.92 & 3.57 & 2.78 & 2.04 \\
\hline & 1.78 & 1.00 & 7.14 & 1.28 & 4.76 & 3.85 & 2.78 & 6.25 & 4.55 & 2.94 \\
\hline \multirow[t]{3}{*}{ C13 } & 0.24 & 0.14 & 1.00 & 0.27 & 0.51 & 0.37 & 0.31 & 0.68 & 0.34 & 0.27 \\
\hline & 0.37 & 0.23 & 1.00 & 0.36 & 0.81 & 0.58 & 0.45 & 1.04 & 0.51 & 0.37 \\
\hline & 0.76 & 0.41 & 1.00 & 0.53 & 1.15 & 1.09 & 0.83 & 1.59 & 0.92 & 0.59 \\
\hline \multirow[t]{3}{*}{ C14 } & 0.52 & 0.78 & 1.89 & 1.00 & 1.79 & 0.89 & 1.15 & 1.59 & 1.72 & 1.10 \\
\hline & 1.21 & 1.17 & 2.76 & 1.00 & 2.78 & 1.47 & 1.89 & 3.23 & 2.56 & 1.54 \\
\hline & 1.97 & 1.86 & 3.76 & 1.00 & 4.17 & 2.38 & 2.56 & 5.26 & 3.70 & 2.94 \\
\hline \multirow[t]{3}{*}{ C15 } & 0.19 & 0.21 & 0.87 & 0.24 & 1.00 & 0.32 & 0.23 & 1.05 & 0.66 & 0.36 \\
\hline & 0.27 & 0.29 & 1.24 & 0.36 & 1.00 & 0.47 & 0.30 & 1.85 & 1.09 & 0.57 \\
\hline & 0.56 & 0.38 & 1.98 & 0.56 & 1.00 & 0.76 & 0.43 & 2.70 & 1.69 & 1.02 \\
\hline \multirow[t]{3}{*}{ C16 } & 0.36 & 0.26 & 0.92 & 0.42 & 1.31 & 1.00 & 0.32 & 1.27 & 1.19 & 0.58 \\
\hline & 0.54 & 0.39 & 1.73 & 0.68 & 2.12 & 1.00 & 0.47 & 2.17 & 1.61 & 0.90 \\
\hline & 0.97 & 0.58 & 2.73 & 1.12 & 3.12 & 1.00 & 0.81 & 3.70 & 2.44 & 1.23 \\
\hline \multirow[t]{3}{*}{ C17 } & 0.75 & 0.36 & 1.21 & 0.39 & 2.32 & 1.24 & 1.00 & 1.64 & 1.15 & 1.59 \\
\hline & 1.12 & 0.52 & 2.21 & 0.53 & 3.32 & 2.12 & 1.00 & 2.56 & 1.54 & 2.08 \\
\hline & 1.57 & 0.89 & 3.21 & 0.87 & 4.32 & 3.12 & 1.00 & 4.17 & 2.44 & 2.70 \\
\hline \multirow[t]{3}{*}{ C18 } & 0.17 & 0.16 & 0.63 & 0.19 & 0.37 & 0.27 & 0.24 & 1.00 & 0.32 & 0.26 \\
\hline & 0.29 & 0.28 & 0.96 & 0.31 & 0.54 & 0.46 & 0.39 & 1.00 & 0.46 & 0.35 \\
\hline & 0.68 & 0.37 & 1.47 & 0.63 & 0.95 & 0.79 & 0.61 & 1.00 & 0.76 & 0.53 \\
\hline \multirow[t]{3}{*}{ C19 } & 0.21 & 0.22 & 1.09 & 0.27 & 0.59 & 0.41 & 0.41 & 1.32 & 1.00 & 0.34 \\
\hline & 0.34 & 0.36 & 1.98 & 0.39 & 0.92 & 0.62 & 0.65 & 2.17 & 1.00 & 0.52 \\
\hline & 0.74 & 0.56 & 2.98 & 0.58 & 1.51 & 0.84 & 0.87 & 3.17 & 1.00 & 0.92 \\
\hline \multirow[t]{3}{*}{ C110 } & 0.62 & 0.34 & 1.69 & 0.34 & 0.98 & 0.81 & 0.37 & 1.89 & 1.09 & 1.00 \\
\hline & 1.08 & 0.49 & 2.69 & 0.65 & 1.76 & 1.11 & 0.48 & 2.89 & 1.91 & 1.00 \\
\hline & 1.78 & 0.83 & 3.69 & 0.91 & 2.76 & 1.72 & 0.63 & 3.89 & 2.91 & 1.00 \\
\hline
\end{tabular}

Source: Author's calculation 
TABLE 5. FINAL PAIRWISE COMPARISON MATRIX OF OPERATIONAL PARAMETERS

\begin{tabular}{|c|c|c|c|c|c|c|c|c|c|}
\hline & C21 & $\mathrm{C} 22$ & $\mathrm{C} 23$ & $\mathrm{C} 24$ & $\mathrm{C} 25$ & $\mathrm{C} 26$ & $\mathrm{C} 27$ & $\mathrm{C} 28$ & C29 \\
\hline \multirow[t]{3}{*}{ C21 } & 1.00 & 0.26 & 0.32 & 0.24 & 0.20 & 0.25 & 0.64 & 0.32 & 0.30 \\
\hline & 1.00 & 0.35 & 0.47 & 0.32 & 0.26 & 0.34 & 0.93 & 0.47 & 0.42 \\
\hline & 1.00 & 0.53 & 0.81 & 0.48 & 0.34 & 0.52 & 1.28 & 0.83 & 0.73 \\
\hline \multirow[t]{3}{*}{ C22 } & 1.87 & 1.00 & 1.22 & 0.39 & 0.33 & 0.36 & 1.47 & 0.45 & 0.32 \\
\hline & 2.87 & 1.00 & 2.08 & 0.65 & 0.49 & 0.56 & 2.86 & 0.81 & 0.46 \\
\hline & 3.87 & 1.00 & 2.94 & 1.03 & 0.89 & 1.12 & 4.17 & 1.47 & 0.70 \\
\hline \multirow[t]{3}{*}{ C23 } & 1.23 & 0.34 & 1.00 & 0.38 & 0.26 & 0.22 & 1.05 & 0.36 & 0.37 \\
\hline & 2.11 & 0.48 & 1.00 & 0.62 & 0.35 & 0.27 & 1.64 & 0.56 & 0.60 \\
\hline & 3.11 & 0.82 & 1.00 & 1.28 & 0.54 & 0.38 & 2.63 & 1.03 & 1.09 \\
\hline \multirow[t]{3}{*}{ C24 } & 2.09 & 0.97 & 0.78 & 1.00 & 0.32 & 0.32 & 2.08 & 0.52 & 0.35 \\
\hline & 3.09 & 1.55 & 1.62 & 1.00 & 0.47 & 0.48 & 3.45 & 0.89 & 0.53 \\
\hline & 4.09 & 2.55 & 2.62 & 1.00 & 0.88 & 0.81 & 4.76 & 1.15 & 0.92 \\
\hline \multirow[t]{3}{*}{ C25 } & 2.92 & 1.12 & 1.85 & 1.14 & 1.00 & 0.32 & 1.92 & 1.06 & 0.45 \\
\hline & 3.92 & 2.04 & 2.85 & 2.14 & 1.00 & 0.48 & 2.56 & 2.13 & 0.81 \\
\hline & 4.92 & 3.04 & 3.85 & 3.14 & 1.00 & 0.79 & 3.85 & 2.94 & 1.15 \\
\hline \multirow[t]{3}{*}{ C26 } & 1.94 & 0.89 & 2.64 & 1.23 & 1.27 & 1.00 & 3.23 & 1.19 & 0.42 \\
\hline & 2.94 & 1.78 & 3.64 & 2.08 & 2.08 & 1.00 & 4.17 & 1.85 & 0.74 \\
\hline & 3.94 & 2.78 & 4.64 & 3.08 & 3.08 & 1.00 & 7.14 & 2.44 & 0.94 \\
\hline \multirow[t]{3}{*}{ C27 } & 0.78 & 0.24 & 0.38 & 0.21 & 0.26 & 0.14 & 1.00 & 0.24 & 0.22 \\
\hline & 1.07 & 0.35 & 0.61 & 0.29 & 0.39 & 0.24 & 1.00 & 0.31 & 0.29 \\
\hline & 1.57 & 0.68 & 0.95 & 0.48 & 0.52 & 0.31 & 1.00 & 0.45 & 0.41 \\
\hline \multirow[t]{3}{*}{ C28 } & 1.21 & 0.68 & 0.97 & 0.87 & 0.34 & 0.41 & 2.23 & 1.00 & 0.38 \\
\hline & 2.12 & 1.24 & 1.78 & 1.12 & 0.47 & 0.54 & 3.23 & 1.00 & 0.61 \\
\hline & 3.12 & 2.24 & 2.78 & 1.92 & 0.94 & 0.84 & 4.23 & 1.00 & 1.02 \\
\hline \multirow[t]{3}{*}{ C29 } & 1.37 & 1.43 & 0.92 & 1.09 & 0.87 & 1.06 & 2.45 & 0.98 & 1.00 \\
\hline & 2.37 & 2.17 & 1.68 & 1.87 & 1.23 & 1.36 & 3.45 & 1.64 & 1.00 \\
\hline & 3.37 & 3.17 & 2.68 & 2.87 & 2.23 & 2.36 & 4.45 & 2.64 & 1.00 \\
\hline
\end{tabular}

Source: Author's calculation 
TABLE 6. FINAL PAIRWISE COMPARISON MATRIX OF ECONOMICAL PARAMETERS

\begin{tabular}{llllllllll}
\hline \hline & & C31 & & & C32 & & \multicolumn{3}{c}{ C33 } \\
\hline C31 & 1.00 & 1.00 & 1.00 & 0.89 & 1.67 & 2.67 & 2.21 & 3.21 & 4.21 \\
C32 & 0.37 & 0.60 & 1.12 & 1.00 & 1.00 & 1.00 & 0.98 & 1.45 & 2.45 \\
C33 & 0.24 & 0.31 & 0.45 & 0.41 & 0.69 & 1.02 & 1.00 & 1.00 & 1.00 \\
\hline \hline
\end{tabular}

Source: Author's calculation

TABLE 7. FINAL PAIRWISE COMPARISON MATRIX OF MAIN CRITERIA

\begin{tabular}{cccccccccc}
\hline \hline & \multicolumn{3}{c}{$\mathrm{C} 1$} & \multicolumn{3}{c}{$\mathrm{C} 2$} & & \multicolumn{3}{c}{$\mathrm{C} 3$} \\
\hline $\mathrm{C} 1$ & 1.00 & 1.00 & 1.00 & 0.78 & 1.19 & 1.86 & 0.94 & 1.23 & 1.67 \\
$\mathrm{C} 2$ & 0.54 & 0.84 & 1.28 & 1.00 & 1.00 & 1.00 & 0.58 & 0.89 & 1.35 \\
$\mathrm{C} 3$ & 0.60 & 0.81 & 1.06 & 0.74 & 1.12 & 1.72 & 1.00 & 1.00 & 1.00 \\
\hline \hline
\end{tabular}

Source: Author's calculation

TABLE 8. VALUES RESULT FOR TECHNICAL PARAMETERS

\begin{tabular}{lcccccccccc}
\hline \hline & $S_{11}$ & $S_{12}$ & $S_{13}$ & $S_{14}$ & $S_{15}$ & $S_{16}$ & $S_{17}$ & $S_{18}$ & $S_{19}$ & $S_{110}$ \\
\hline$V\left(S_{11} \geq \cdots\right)$ & & 1 & 0.4 & 1 & 0.42 & 0.72 & 0.93 & 0.34 & 0.55 & 0.82 \\
$V\left(S_{12} \geq \cdots\right)$ & 0.85 & & 0.2 & 0.97 & 0.21 & 0.53 & 0.76 & 0.14 & 0.34 & 0.63 \\
$V\left(S_{13} \geq \cdots\right)$ & 1 & 1 & & 1 & 1 & 1 & 1 & 0.95 & 1 & 1 \\
$V\left(S_{14} \geq \cdots\right)$ & 0.89 & 1 & 0.27 & & 0.28 & 0.59 & 0.81 & 0.21 & 0.42 & 0.69 \\
$V\left(S_{15} \geq \cdots\right)$ & 1 & 1 & 0.97 & 1 & & 1 & 1 & 0.91 & 1 & 1 \\
$V\left(S_{16} \geq \cdots\right)$ & 1 & 1 & 0.68 & 1 & 0.7 & & 1 & 0.61 & 0.84 & 1 \\
$V\left(S_{17} \geq \cdots\right)$ & 1 & 1 & 0.42 & 1 & 0.44 & 0.77 & & 0.36 & 0.59 & 0.88 \\
$V\left(S_{18} \geq \cdots\right)$ & 1 & 1 & 1 & 1 & 1 & 1 & 1 & & 1 & 1 \\
$V\left(S_{19} \geq \cdots\right)$ & 1 & 1 & 0.85 & 1 & 0.88 & 1 & 1 & 0.79 & & 1 \\
$V\left(S_{110} \geq \cdots\right)$ & 1 & 1 & 0.57 & 1 & 0.6 & 0.91 & 1 & 0.51 & 0.73 & \\
\hline \hline
\end{tabular}

Source: Author's calculation 
TABLE 9. $V$ VALUES RESULT FOR OPERATIONAL PARAMETERS

\begin{tabular}{cccccccccc}
\hline \hline & $S_{21}$ & $S_{22}$ & $S_{23}$ & $S_{24}$ & $S_{25}$ & $S_{26}$ & $S_{27}$ & $S_{28}$ & $S_{29}$ \\
\hline$V\left(S_{21} \geq \cdots\right)$ & & 1 & 1 & 1 & 1 & 1 & 0.95 & 1 & 1 \\
$V\left(S_{22} \geq \cdots\right)$ & 0.59 & & 0.79 & 1 & 1 & 1 & 0.53 & 1 & 1 \\
$V\left(S_{23} \geq \cdots\right)$ & 0.8 & 1 & & 1 & 1 & 1 & 0.75 & 1 & 1 \\
$V\left(S_{24} \geq \cdots\right)$ & 0.53 & 0.95 & 0.74 & & 1 & 1 & 0.47 & 1 & 1 \\
$V\left(S_{25} \geq \cdots\right)$ & 0.27 & 0.72 & 0.49 & 0.77 & & 1 & 0.21 & 0.79 & 1 \\
$V\left(S_{26} \geq \cdots\right)$ & 0.12 & 0.56 & 0.33 & 0.61 & 0.86 & & 0.05 & 0.64 & 0.98 \\
$V\left(S_{27} \geq \cdots\right)$ & 1 & 1 & 1 & 1 & 1 & 1 & & 1 & 1 \\
$V\left(S_{28} \geq \cdots\right)$ & 0.48 & 0.93 & 0.69 & 0.97 & 1 & 1 & 0.42 & & 1 \\
$V\left(S_{29} \geq \cdots\right)$ & 0.11 & 0.56 & 0.32 & 0.61 & 0.87 & 1 & 0.04 & 0.64 & 1 \\
\hline \hline
\end{tabular}

Source: Author's calculation

TABLE 10. $V$ VALUES RESULT FOR ECONOMICAL PARAMETERS

\begin{tabular}{cccc}
\hline \hline & $S_{31}$ & $S_{32}$ & $S_{33}$ \\
\hline$V\left(S_{31} \geq \cdots\right)$ & & 1 & 1 \\
$V\left(S_{32} \geq \cdots\right)$ & 0.53 & & 1 \\
$V\left(S_{33} \geq \cdots\right)$ & 0.08 & 0.61 &
\end{tabular}

Source: Author's calculation 
TABLE 11. $V$ VALUES RESULT FOR MAIN CRITERIA

\begin{tabular}{cccc}
\hline \hline & $S_{1}$ & $S_{2}$ & $S_{3}$ \\
\hline$V\left(S_{1} \geq \cdots\right)$ & & 1 & 1 \\
$V\left(S_{2} \geq \cdots\right)$ & 0.79 & & 0.93 \\
$V\left(S_{3} \geq \cdots\right)$ & 0.85 & 1 &
\end{tabular}

Source: Author's calculation

The value of fuzzy synthetic extent with respect to the ith object is calculated as $S_{11}=(4.8,7.33,11.81) \otimes(0.005,0.008,0.012)=(0.024,0.055,0.138)$

$S_{12}=(4.03,5.63,8.23) \otimes(0.005,0.008,0.012)=(0.02,0.043,0.096)$

$S_{13}=(13.05,21.62,32.13) \otimes(0.005,0.008,0.012)=(0.066,0.163,0.375)$

$S_{14}=(4.16,5.96,9.4) \otimes(0.005,0.008,0.012)=(0.021,0.045,0.11)$

$S_{15}=(13.28,20.4,29.0) \otimes(0.005,0.008,0.012)=(0.067,0.154,0.339)$

$S_{16}=(8.06,12.25,18.33) \otimes(0.005,0.008,0.012)=(0.041,0.093,0.214)$

$S_{17}=(5.79,8.45,11.85) \otimes(0.005,0.008,0.012)=(0.029,0.064,0.138)$

$S_{18}=(14.61,23.94,37.62) \otimes(0.005,0.008,0.012)=(0.073,0.181,0.439)$

$S_{19}=(10.6,16.4,25.17) \otimes(0.005,0.008,0.012)=(0.053,0.124,0.294)$

$S_{110}=(7.27,10.3,15.49) \otimes(0.005,0.008,0.012)=(0.037,0.078,0.181)$

$S_{21}=(14.41,21.49,28.99) \otimes(0.006,0.009,0.014)=(0.09,0.2,0.4)$

$S_{22}=(6.93,10.96,16.81) \otimes(0.006,0.009,0.014)=(0.04,0.1,0.23)$

$S_{23}=(10.08,15.74,22.27) \otimes(0.006,0.009,0.014)=(0.06,0.14,0.31)$

$S_{24}=(6.56,10.09,15.28) \otimes(0.006,0.009,0.014)=(0.04,0.09,0.21)$

$S_{25}=(4.85,6.73,10.42) \otimes(0.006,0.009,0.014)=(0.03,0.06,0.14)$

$S_{26}=(4.09,5.28,8.13) \otimes(0.006,0.009,0.014)=(0.03,0.05,0.11)$ 


$$
\begin{aligned}
& S_{27}=(16.07,23.29,33.51) \otimes(0.006,0.009,0.014)=(0.1,0.21,0.46) \\
& S_{28}=(6.12,9.66,13.95) \otimes(0.006,0.009,0.014)=(0.04,0.09,0.19) \\
& S_{29}=(3.81,5.46,7.96) \otimes(0.006,0.009,0.014)=(0.02,0.05,0.11) \\
& S_{31}=(4.1,5.88,7.88) \otimes(0.067,0.091,0.123)=(0.27,0.54,0.97) \\
& S_{32}=(2.35,3.05,4.57) \otimes(0.067,0.091,0.123)=(0.16,0.28,0.56) \\
& S_{33}=(1.65,2.0,2.47) \otimes(0.067,0.091,0.123)=(0.11,0.18,0.31) \\
& S_{1}=(2.72,3.42,4.53) \otimes(0.084,0.11,0.139)=(0.23,0.38,0.63) \\
& S_{2}=(2.12,2.73,3.63) \otimes(0.084,0.11,0.139)=(0.18,0.3,0.51) \\
& S_{3}=(2.34,2.94,3.79) \otimes(0.084,0.11,0.139)=(0.2,0.32,0.53)
\end{aligned}
$$

Then priority weights are computed by using Eq. (9):

$$
\begin{aligned}
& d^{\prime}(C 11)=\min (1,0.4,1,0.42,0.72,0.93,0.34,0.55,0.82)=0.4 \\
& d^{\prime}(C 12)=\min (0.85,0.2,0.97,0.21,0.53,0.76,0.14,0.34,0.63)=0.14 \\
& d^{\prime}(C 13)=\min (1,1,1,1,1,1,0.95,1,1)=0.95 \\
& d^{\prime}(C 14)=\min (0.89,1,0.27,0.28,0.59,0.81,0.21,0.42,0.69)=0.21 \\
& d^{\prime}(C 15)=\min (1,1,0.97,1,1,1,0.91,1,1)=0.91 \\
& d^{\prime}(C 16)=\min (1,1,0.68,1,0.7,1,0.61,0.84,1)=0.61 \\
& d^{\prime}(C 17)=\min (1,1,0.42,1,0.44,0.77,0.36,0.59,0.88)=0.36 \\
& d^{\prime}(C 18)=\min (1,1,1,1,1,1,1,1,1)=1 \\
& d^{\prime}(C 19)=\min (1,1,0.85,1,0.88,1,1,0.79,1)=0.79 \\
& d^{\prime}(C 110)=\min (1,1,0.57,1,0.6,0.91,1,0.51,0.73)=0.51 \\
& d^{\prime}(C 21)=\min (1,1,1,1,1,0.95,1,1)=0.95 \\
& d^{\prime}(C 22)=\min (0.59,0.79,1,1,1,0.53,1,1)=0.53 \\
& d^{\prime}(C 23)=\min (0.8,1,1,1,1,0.75,1,1)=0.75 \\
& d^{\prime}(C 24)=\min (0.53,0.95,0.74,1,1,0.47,1,1)=0.47 \\
& d^{\prime}(C 25)=\min (0.27,0.72,0.49,0.77,1,0.21,0.79,1)=0.21
\end{aligned}
$$




$$
\begin{aligned}
& d^{\prime}(C 26)=\min (0.12,0.56,0.33,0.61,0.86,0.05,0.64,0.98)=0.05 \\
& d^{\prime}(C 27)=\min (1,1,1,1,1,1,1,1)=1 \\
& d^{\prime}(C 28)=\min (0.48,0.93,0.69,0.97,1,1,0.42,1)=0.42 \\
& d^{\prime}(C 29)=\min (0.11,0.56,0.32,0.61,0.87,1,0.04,0.64)=0.04 \\
& d^{\prime}(C 31)=\min (1,1)=1 \\
& d^{\prime}(C 32)=\min (0.53,1)=0.53 \\
& d^{\prime}(C 33)=\min (0.08,0.61)=0.08 \\
& d^{\prime}(C 1)=\min (1,1)=1 \\
& d^{\prime}(C 2)=\min (0.79,0.93)=0.79 \\
& d^{\prime}(C 33)=\min (0.85,1)=0.85
\end{aligned}
$$

The global weights of evaluation criteria are calculated by multiplying local weight of the evaluation indicators with the weights of the main criteria to which it belongs. After the computation of these values priority weights respect to main objective are obtained as (0.024, $0.01,0.067,0.015,0.064,0.043,0.025,0.071,0.056,0.036,0.061,0.034,0.048,0.03,0.014,0.003$, $0.064,0.027,0.003,0.216,0.078,0.012$ ). Mentioned priority weights have presented for each criterion in Table 12. The results of the FAHP analysis for relative weights of the evaluation criteria are summarized in Fig. 7. 
TABLE 12. PRIORITY WEIGHTS FOR CRITERIA

\begin{tabular}{|c|c|c|}
\hline Criteria & Local weights & Global weights \\
\hline $\mathrm{C} 1$ & 0.411 & \\
\hline C11 & 0.058 & 0.024 \\
\hline $\mathrm{C} 12$ & 0.024 & 0.01 \\
\hline C13 & 0.162 & 0.067 \\
\hline C14 & 0.036 & 0.015 \\
\hline C15 & 0.156 & 0.064 \\
\hline C16 & 0.105 & 0.043 \\
\hline C17 & 0.061 & 0.025 \\
\hline C18 & 0.172 & 0.071 \\
\hline C19 & 0.137 & 0.056 \\
\hline C110 & 0.088 & 0.036 \\
\hline $\mathrm{C} 2$ & 0.283 & \\
\hline C21 & 0.215 & 0.061 \\
\hline $\mathrm{C} 22$ & 0.120 & 0.034 \\
\hline $\mathrm{C} 23$ & 0.169 & 0.048 \\
\hline C24 & 0.106 & 0.03 \\
\hline $\mathrm{C} 25$ & 0.048 & 0.014 \\
\hline C26 & 0.012 & 0.003 \\
\hline $\mathrm{C} 27$ & 0.227 & 0.064 \\
\hline $\mathrm{C} 28$ & 0.094 & 0.027 \\
\hline C29 & 0.009 & 0.003 \\
\hline C3 & 0.306 & \\
\hline C31 & 0.707 & 0.216 \\
\hline C32 & 0.255 & 0.078 \\
\hline C33 & 0.038 & 0.012 \\
\hline
\end{tabular}

Source: Author's calculation 


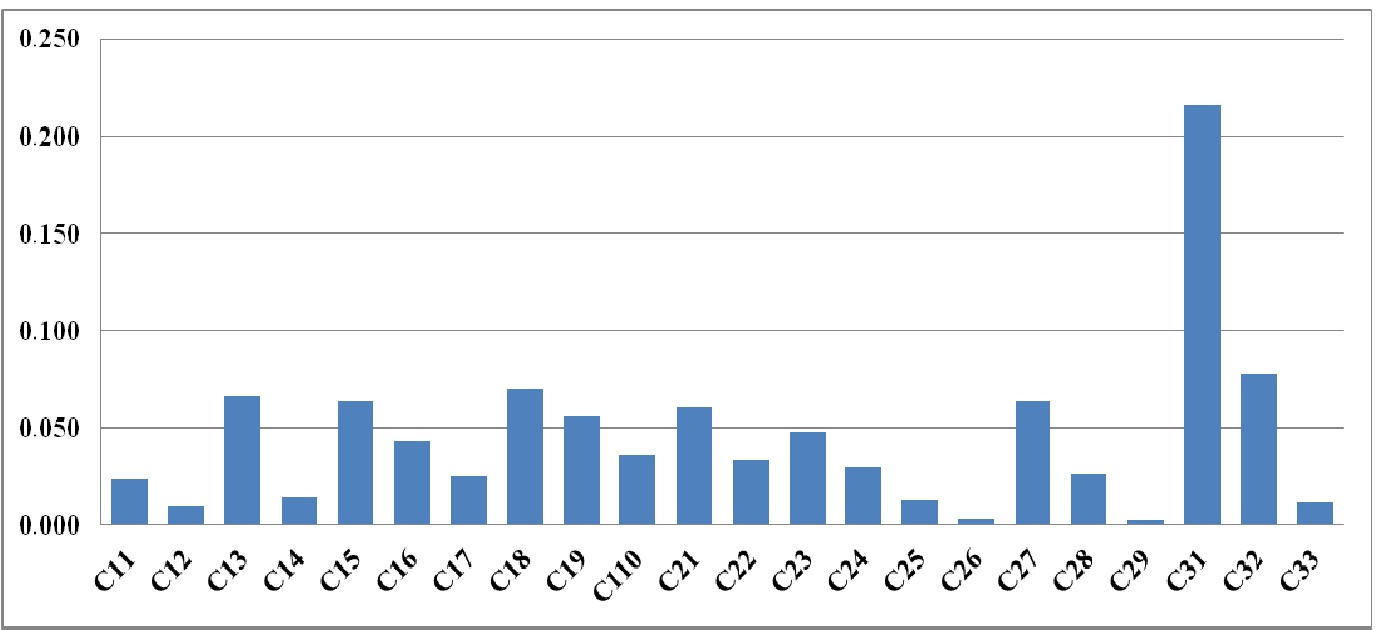

FIGURE. 7. RELATIVE WEIGHTS OF CRITERIA

Source: Author's calculation

\section{Determine the final rank and select the best alternative through FTOPSIS}

In this step, fuzzy evaluation matrices are established by fifteendecision makers for evaluating theunderground mining methods under different criteria based on linguistic variables listed in Table 2 and shown in Fig. 3. For the benefit criteria (C11, C12, C13, C14, C15, C16, C17, C18, C19, $\mathrm{C} 110, \mathrm{C} 21, \mathrm{C} 22, \mathrm{C} 23, \mathrm{C} 26$, and $\mathrm{C} 27)$, the higher the score, the better the performance of the mining method is; whereas, for the cost criteria (C24, C25, C28, C29, C31, C32, and C33), the higher the score, the worse the performance of the mining method is.For example, the fuzzy decision matrix filled by one of the decision makers is presented in Table 13. 
TABLE 13. SAMPLE OF FILLED QUESTIONNAIRE

\begin{tabular}{|c|c|c|c|c|c|c|}
\hline & $\mathrm{A} 1$ & $\mathrm{~A} 2$ & $\mathrm{~A} 3$ & A4 & A5 & A6 \\
\hline C11 & $P$ & VG & $G$ & $G$ & $G$ & $F$ \\
\hline $\mathrm{C} 12$ & $\mathrm{~F}$ & $G$ & $G$ & VG & $G$ & $G$ \\
\hline C13 & $P$ & $G$ & $F$ & $\mathrm{G}$ & $G$ & VG \\
\hline C14 & $G$ & $G$ & $G$ & $G$ & $\mathrm{~F}$ & $G$ \\
\hline $\mathrm{C} 15$ & $G$ & VG & $\mathrm{F}$ & VG & $G$ & $G$ \\
\hline $\mathrm{C} 16$ & $\mathrm{~F}$ & $G$ & $\mathrm{~F}$ & G & $G$ & $G$ \\
\hline $\mathrm{C} 17$ & $\mathrm{~F}$ & $G$ & $G$ & $G$ & $G$ & $G$ \\
\hline C18 & $\mathrm{F}$ & $G$ & $\mathrm{~F}$ & VG & $\mathrm{F}$ & $G$ \\
\hline C19 & $\mathrm{F}$ & $G$ & $\mathrm{~F}$ & G & $G$ & G \\
\hline C110 & $\mathrm{F}$ & $G$ & $G$ & $G$ & $G$ & $G$ \\
\hline $\mathrm{C} 21$ & $G$ & $P$ & $\mathrm{~F}$ & $G$ & $\mathrm{~F}$ & $G$ \\
\hline $\mathrm{C} 22$ & $P$ & $P$ & $F$ & G & $F$ & $F$ \\
\hline $\mathrm{C} 23$ & VP & $\mathrm{F}$ & VP & VG & $\mathrm{F}$ & $G$ \\
\hline $\mathrm{C} 24$ & VG & $\mathrm{F}$ & $G$ & $P$ & $\mathrm{~F}$ & $P$ \\
\hline $\mathrm{C} 25$ & VG & $\mathrm{F}$ & $G$ & VP & $G$ & $P$ \\
\hline $\mathrm{C} 26$ & VP & $G$ & $P$ & VG & $\mathrm{F}$ & $G$ \\
\hline $\mathrm{C} 27$ & VG & G & $G$ & $G$ & $\mathrm{~F}$ & VP \\
\hline $\mathrm{C} 28$ & VG & $\mathrm{F}$ & $P$ & VP & $\mathrm{F}$ & $\mathrm{F}$ \\
\hline $\mathrm{C} 29$ & $P$ & $\mathrm{~F}$ & $P$ & $P$ & $\mathrm{~F}$ & VG \\
\hline C31 & VP & $\mathrm{F}$ & $P$ & $\mathrm{~F}$ & $\mathrm{~F}$ & VG \\
\hline C 32 & G & $G$ & G & $P$ & $G$ & VG \\
\hline C33 & VG & $\mathrm{F}$ & VG & VP & $\mathrm{F}$ & $P$ \\
\hline
\end{tabular}

Source: Author's calculation

Then, the aggregated fuzzy performance ratings of mining methods with respect to each criterion are computed by Eq. (12) and the results are presented in Table 14. 
TABLE 14. AGGREGATED FUZZY PERFORMANCE RATINGS

\begin{tabular}{|c|c|c|c|c|c|c|c|c|c|c|c|c|c|c|c|c|c|c|}
\hline & & A 1 & & & A 2 & & & A 3 & & & A 4 & & & A 5 & & & A 6 & \\
\hline C11 & & 0.30 & 0.45 & 0.65 & 0.80 & 0.95 & 0.55 & 0.69 & 0.83 & 0.53 & 0.68 & 0.83 & 0.55 & 0.69 & 0.83 & 0.27 & 0.38 & 0.50 \\
\hline C12 & 0.25 & 0.37 & 0.49 & 0.53 & 0.66 & 0.80 & 0.57 & 0.70 & 0.84 & 0.67 & 0.82 & 0.97 & 0.56 & 0.69 & 0.82 & 0.56 & 0.70 & 0.84 \\
\hline C13 & 0.13 & 0.28 & 0.43 & 0.53 & 0.67 & 0.81 & 0.37 & 0.49 & 0.61 & 0.55 & 0.70 & 0.84 & 0.54 & 0.68 & 0.82 & 0.65 & 0.80 & 0.94 \\
\hline C14 & 0.55 & 0.70 & 0.84 & 0.55 & 0.69 & 0.83 & 0.56 & 0.71 & 0.86 & 0.57 & 0.72 & 0.86 & 0.37 & 0.48 & 0.60 & 0.57 & 0.71 & 0.85 \\
\hline C15 & 0.57 & 0.70 & 0.83 & 0.63 & 0.78 & 0.93 & 0.39 & 0.54 & 0.69 & 0.65 & 0.79 & 0.94 & 0.56 & 0.69 & 0.82 & 0.57 & 0.70 & 0.84 \\
\hline C 16 & 0.27 & 0.38 & 0.49 & 0.52 & 0.66 & 0.79 & 0.34 & 0.46 & 0.59 & 0.55 & 0.68 & 0.81 & 0.55 & 0.69 & 0.83 & 0.59 & 0.74 & 0.88 \\
\hline C17 & 0.29 & 0.41 & 0.53 & 0.55 & 0.69 & 0.83 & 0.57 & 0.72 & 0.87 & 0.53 & 0.66 & 0.79 & 0.52 & 0.65 & 0.78 & 0.54 & 0.68 & 0.81 \\
\hline C18 & 0.41 & 0.53 & 0.65 & 0.57 & 0.71 & 0.84 & 0.42 & 0.56 & 0.70 & 0.56 & 0.71 & 0.83 & 0.33 & 0.46 & 0.59 & 0.56 & 0.71 & 0.86 \\
\hline C19 & 0.31 & 0.43 & 0.55 & 0.56 & 0.71 & 0.86 & 0.41 & 0.54 & 0.66 & 0.52 & 0.66 & 0.81 & 0.53 & 0.68 & 0.83 & 0.53 & 0.67 & 0.81 \\
\hline C110 & 0.28 & 0.39 & 0.50 & 0.52 & 0.66 & 0.80 & 0.54 & 0.68 & 0.81 & 0.53 & 0.67 & 0.81 & 0.50 & 0.64 & 0.78 & 0.53 & 0.67 & 0.81 \\
\hline C21 & 0.56 & 0.69 & 0.83 & 0.17 & 0.30 & 0.43 & 0.37 & 0.52 & 0.67 & 0.51 & 0.64 & 0.78 & 0.42 & 0.53 & 0.65 & 0.55 & 0.69 & 0.83 \\
\hline C22 & 0.15 & 0.28 & 0.42 & 0.16 & 0.31 & 0.46 & 0.31 & 0.45 & 0.59 & 0.56 & 0.68 & 0.81 & 0.41 & 0.56 & 0.71 & 0.41 & 0.53 & 0.65 \\
\hline C23 & 0.07 & 0.22 & 0.37 & 0.42 & 0.54 & 0.66 & 0.08 & 0.23 & 0.38 & 0.64 & 0.79 & 0.94 & 0.38 & 0.49 & 0.61 & 0.57 & 0.72 & 0.86 \\
\hline C24 & 0.63 & 0.78 & 0.93 & 0.29 & 0.41 & 0.53 & 0.15 & 0.29 & 0.43 & 0.39 & 0.51 & 0.63 & 0.51 & 0.65 & 0.79 & 0.14 & 0.28 & 0.43 \\
\hline$C 25$ & 0.63 & 0.78 & 0.93 & 0.31 & 0.43 & 0.55 & 0.57 & 0.70 & 0.84 & 0.05 & 0.20 & 0.35 & 0.53 & 0.66 & 0.80 & 0.16 & 0.31 & 0.46 \\
\hline C26 & 0.09 & 0.24 & 0.39 & 0.55 & 0.63 & 0.71 & 0.13 & 0.26 & 0.39 & 0.63 & 0.78 & 0.93 & 0.30 & 0.41 & 0.53 & 0.59 & 0.74 & 0.89 \\
\hline C27 & 0.63 & 0.78 & 0.93 & 0.58 & 0.72 & 0.85 & 0.53 & 0.68 & 0.83 & 0.57 & 0.71 & 0.85 & 0.37 & 0.49 & 0.61 & 0.05 & 0.20 & 0.35 \\
\hline C28 & 0.66 & 0.81 & 0.96 & 0.37 & 0.50 & 0.62 & 0.17 & 0.32 & 0.46 & 0.08 & 0.23 & 0.38 & 0.39 & 0.51 & 0.62 & 0.43 & 0.55 & 0.67 \\
\hline C29 & 0.17 & 0.31 & 0.45 & 0.32 & 0.44 & 0.55 & 0.15 & 0.28 & 0.41 & 0.17 & 0.30 & 0.44 & 0.41 & 0.52 & 0.64 & 0.65 & 0.79 & 0.93 \\
\hline C31 & 0.05 & 0.20 & 0.35 & 0.40 & 0.51 & 0.62 & 0.17 & 0.29 & 0.42 & 0.44 & 0.57 & 0.70 & 0.40 & 0.55 & 0.70 & 0.66 & 0.80 & 0.93 \\
\hline C 32 & 0.54 & 0.68 & 0.81 & 0.48 & 0.62 & 0.76 & 0.58 & 0.71 & 0.83 & 0.17 & 0.30 & 0.44 & 0.55 & 0.68 & 0.81 & 0.68 & 0.83 & 0.98 \\
\hline C 33 & 0.65 & 0.79 & 0.93 & 0.31 & 0.44 & 0.57 & 0.65 & 0.80 & 0.95 & 0.08 & 0.23 & 0.38 & 0.33 & 0.44 & 0.56 & 0.15 & 0.29 & 0.43 \\
\hline
\end{tabular}

Source: Author's calculation

After forming the fuzzy evaluation matrix, the second phase is to calculatethe normalized fuzzydecision matrix using Eq. (15). Next, using the criteria weights obtained by FAHP, the weighted decision matrix is derived as presented in Table 15. 
TABLE 15. WEIGHTED DECISION MATRIX

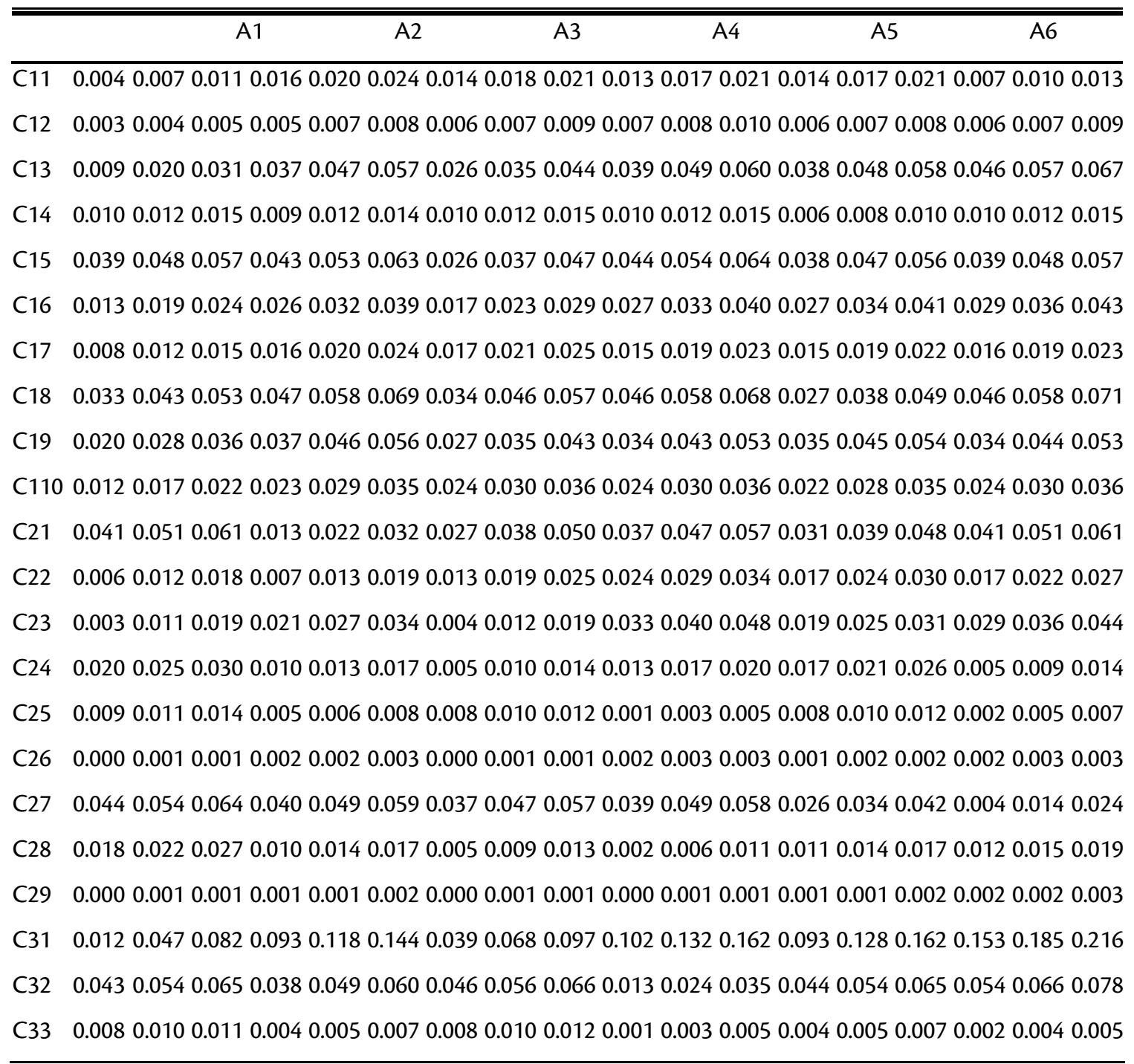

Source: Author's calculation

After forming the weighted decision matrix, the fuzzy positive-ideal solution (FPIS, $A^{*}$ ) and the fuzzynegative-ideal solution (FPIS, $A^{-}$) are derived as $A^{*}=(1,1,1)$ and $A^{-}=(0,0,0)$ for benefit criteria, and $A^{*}=(0,0,0)$ and $A^{-}=(1,1,1)$ for cost criteria.

Finally, alternatives are ranked in descending order as presented in Table 16. According to $C C_{i}$ values, the ranking of the alternatives in descending order are A4, A2, A3, A5, A1 and A6. The proposed model indicates that Cut \& Fill (A4) is the best method with CC value of 0.3322 . Rankings of the alternatives according to $\mathrm{CC}_{\mathrm{i}}$ values are depicted in Fig. 8. 
TABLE 16. FUZZY TOPSIS RESULTS

\begin{tabular}{lcccc}
\hline \hline & $d_{i}^{+}$ & $d_{i}^{-}$ & $C C_{i}$ & Rank \\
\hline A1 & 14.841 & 7.179 & 0.326 & 5 \\
A2 & 14.772 & 7.24 & 0.3289 & 2 \\
A3 & 14.79 & 7.226 & 0.3282 & 3 \\
A4 & 14.67 & 7.313 & 0.3322 & 1 \\
A5 & 14.824 & 7.188 & 0.3265 & 4 \\
A6 & 14.843 & 7.17 & 0.3257 & 6 \\
\hline \hline
\end{tabular}

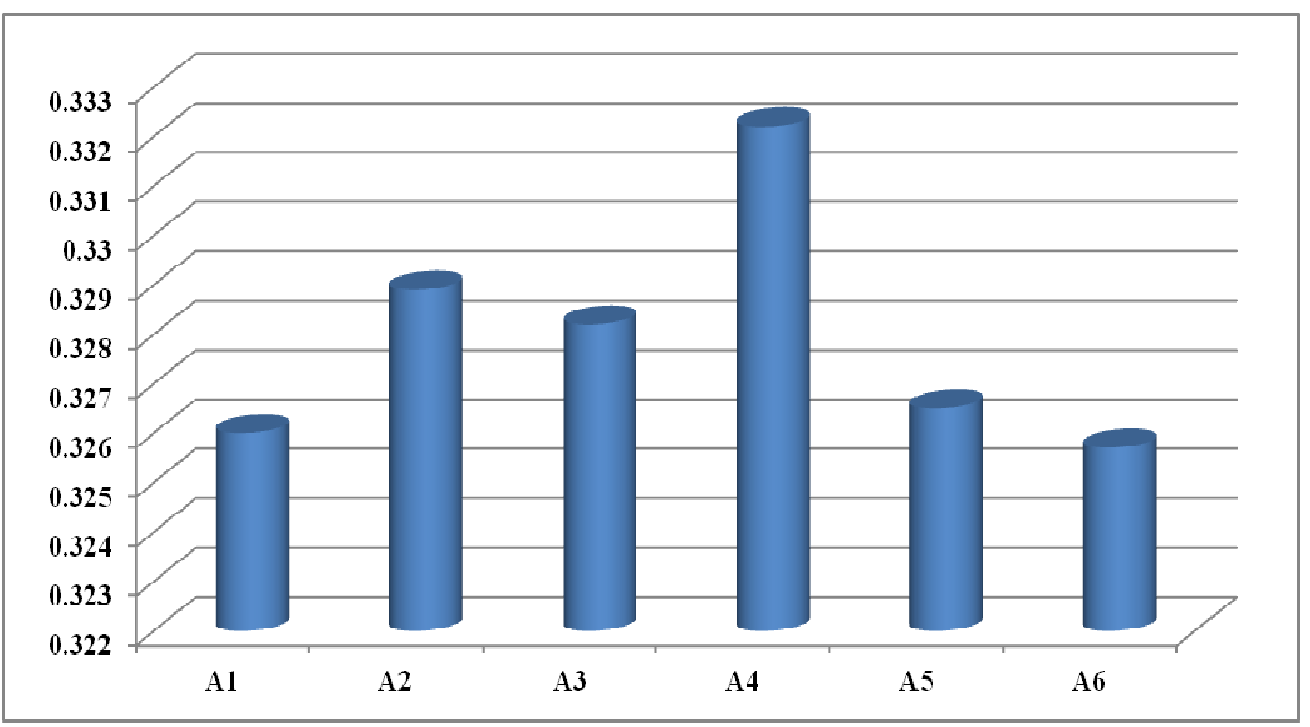

FIGURE. 8. FINAL RANK OF ALTERNATIVES

Source: Author's calculation

\section{SENSITIVITY ANALYSIS}

In order to identify thecause of the difference in the outcome of the proposed model, a sensitivity analysis is conducted. This technique generates different scenarios that may change the priority of alternatives and be needed to reach a consensus. If the ranking order be changed by increasing or decreasing the importance of the criteria, the results are expressed to be sensitive otherwise it is robust. In this study, sensitivity analysis is implemented to see how sensitive the alternatives change with the importance of the criteria. This tool graphical exposes the importance of criteria weights in selecting the optimal alternative among the feasible alternatives. The main goal of sensitivity analysis is to see which criteria is most significant in influencing the decision making process. For this reason, twenty two experiments were conducted that each experiment is 
generatedbyan increase of $100 \%$ in the amount of the weight of the criterion under consideration.

It can be shown from Fig. 9 that alternative A4 has the highest score in twenty two experiments. Therefore, it can be resulted that the decision making process is not sensitive to the criteria weight with alternative $\mathrm{A} 4$ emerging as the winner.

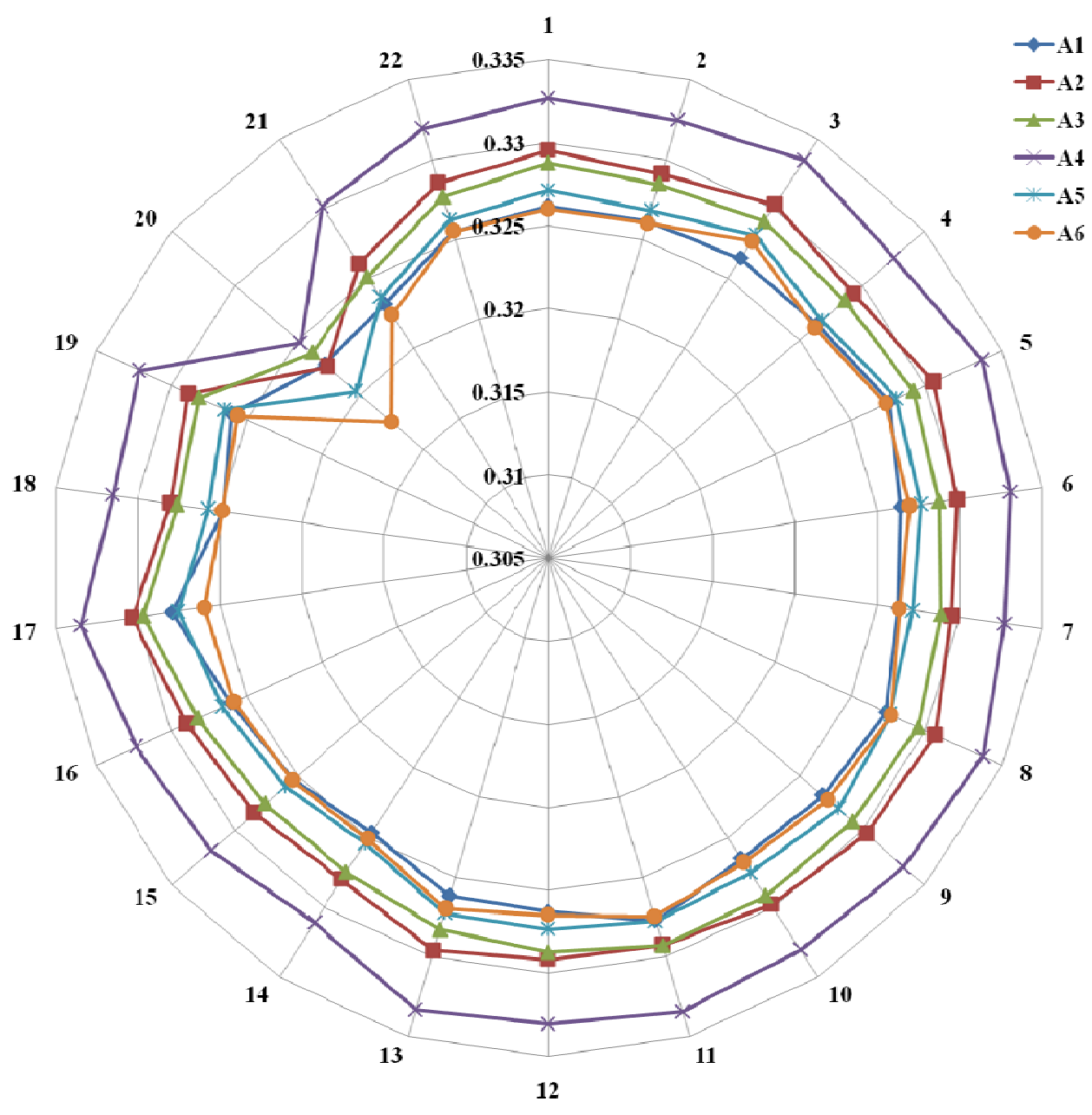

FIGURE. 9. SENSITIVITY ANALYSIS

Source: Author's calculation

\section{CONCLUSION}

The process of mining method selection is a methodology for evaluating the proper alternatives and selecting the best alternative with respect to criteria under consideration. The main goal of this study is to evaluate the feasible alternatives and select the most appropriate candidate 
among a pool of alternatives by using theMCDM methods. According to the complex structure of the problem,inaccurate and imprecise data,less of information, and inherent uncertainty, the usage of the fuzzy sets can be useful. In other words, in such situations using linguistic preferences can be very valuable.

In this paper, an integrated model based on FAHP and FTOPSIS is developed. FAHP based on the extent analysis techniqueis applied to obtain weights of the evaluation criteria, while FTOPSIS is utilized to prioritize the feasible alternatives. The weights derived from FAHP are involved in the problem of the mining method selection by using them in FTOPSIS calculations and ranking order is determined based on these weights. Finally, the alternative with the highest score is selected. Also, sensitivity analysis was conducted to determine the influence of criteria weights on the problem of the mining method selection. The strength of the proposed model is the ability to evaluate and rank alternatives under partial or lack of quantitative information. In order to demonstrate the potential application of the proposed model, a real world case study was implemented.

\section{Acknowledgement}

The authors would like to acknowledge the financial support of University of Tehran for this research.

\section{REFERENCES}

Alpay, S., Yavuz, M., (2009). Underground mining method selection by decision making tools. Tunnelling and Underground Space Technology 24(2): 173-184.

Alpay, S., Yavuz, M., (2007). A decision support system for underground mining method selection. IEA/AIE'07 Proceedings of the 20th international conference on Industrial, engineering, and other applications of applied intelligent systems, 195-206.

Anagnostopoulos, K., Doukas, H., Psarras, J. (2008). A linguistic multicriteria analysis system combining fuzzy sets theory, ideal and anti-ideal points for location site selection. Expert Systems with Applications35(4): 2041-2048.

Antuchevičienè, J., Zakarevičius, A., Zavadskas, E. K. (2011). Measuring congruence of ranking results applying particular MCDM methods. Informatica 22(3): 319-338.

Antuchevičiene, J., Zavadskas, E.K., Zakarevičius, A. (2010). Multiple criteria construction management decisions considering relations between criteria. Technological and Economic Development of Economy 16(1): 109-125.

Ashtiani, B., Haghighirad, F., Makui, A., Montazer, G. (2009). Extension of fuzzy TOPSIS method based on interval-valued fuzzy sets. Applied Soft Computing 9(2): 457-461.

Awasthi, A., Chauhan, S.S. (2012). A hybrid approach integrating Affinity Diagram, AHP and fuzzy TOPSIS for sustainable city logistics planning. Applied Mathematical Modelling 36(2): 573-584.

Awasthi, A., Chauhan, S.S., Omrani, H., Panahi, A. (2011a). A hybrid approach based on SERVQUAL and fuzzy TOPSIS for evaluating transportation service quality. Computers \& Industrial Engineering 61(3): 637-646.

Awasthi, A., Chauhan, S.S., Omrani, H., (2011b). Application of fuzzy TOPSIS in evaluating sustainable transportation systems. Expert Systems with Applications 38: 12270-12280.

Aydogan, E.K. (2011). Performance measurement model for Turkish aviation firms using the rough-AHP and TOPSIS methods under fuzzy environment. Expert Systems with Applications 38(4): 3992-3998.

Azadeh, A. M., Osanloo, M. Ataei, M. (2010). A new approach to mining method selection based on modifying the Nicholas technique. Applied Soft Computing 10(4): 1040-1061. 
Azimi, R., Yazdani-Chamzini, A., Fooladgar, M.M., Basiri, M.H. (2011). Evaluating the strategies of the Iranian mining sector using a integrated model. International Journal of Management Science and Engineering Management 6(6): 459-466.

Bangian, A. H., Ataei, M., Sayadi, A.R., Gholinegad, A.R. (2011). Fuzzy analytical hierarchy processing to define optimum post mining land use for pit area to clarify reclamation costs. Mineral resources management - Gospodarka surowcami mineralnymi56(2): 145-168.

Bazzaz, A.A., Osanloo, M., Karimi, B. (2011). A new fuzzy multi criteria decision making model for open pit mines equipment selection. Asia-Pacific Journal of Operational Research 28(3): 279-300.

Bazzaz, A.A., Osanloo, M., Karimi, B. (2009). Optimal Open Pit Mining Equipment Selection Using Fuzzy Multiple Attribute Decision Making Approach. Archive of Mining Science 54(2): 301-320.

Bazzaz, A.A., Osanloo, M., Soltanmohammadi, H. (2008). Loading-haulage equipment selection in open pit mines based on fuzzy-TOPSIS method.Mineral Resources Management Gospodarka Surowcami Mineralnymi 24(4): 87-102.

Boender, C.G.E., de Grann, J.G., Lootsma, F.A. (1989). Multicriteria decision analysis with fuzzy pairwise comparison. Fuzzy Sets and Systems 29: 133-143.

Boni, M., Gilg, H.A., Balassone, G., Schneider, J., Allen, C.R., Moore, F. (2007). Hypogene Zn carbonate ores in the Angouran deposit. NW Iran. Miner Deposita 42(8):799-820.

Boshkov, S.H., Wright, F.D. (1973). Basic and parametric criteria in the selection, design and development of underground mining systems. SME Mining Engineering Handbook. SMEAIME, New York.

Braglia, M., Frosolini, M., Montanari, R. (2003). Fuzzy TOPSIS approach for failure mode, effects and criticality analysis. Quality and Reliability Engineering International 19(5): 425-443.

Buckley, J.J. (1985). Fuzzy hierarchical analysis, Fuzzy Sets and Systems 17: 233-247.

Büyüközkan, G., Çifçi, G. (2012). A combined fuzzy AHP and fuzzy TOPSIS based strategic analysis of electronic service quality in healthcare industry. Expert Systems with Applications 39(3): 2341-2354.

Chan, F.T.S., Kumar, N. (2007). Global supplier development considering risk factors using fuzzy extended AHP-based approach. Omega 35: 417-431.

Chang, Ch.H., Lin, J.J., Lin, J.H., Chiang, M.Ch. (2010). Domestic open-end equity mutual fund performance evaluation using extended TOPSIS method with different distance approaches. Expert Systems with Applications 37(6): 4642-4649.

Chang, D.Y. (1996). Applications of the extent analysis method on fuzzy AHP. European Journal of Operational Research 95: 649-655.

Chen, T.Y. (2011). Interval-valued fuzzy TOPSIS method with leniency reduction and an experimental analysis. Applied Soft Computing 11(8): 4591-4606.

Chen, Z., Yang, W. (2011). An MAGDM based on constrained FAHP and FTOPSIS and its application to supplier selection. Mathematical and Computer Modelling 54(11-12): 28022815.

Chen, L.H., Hung, Ch.Ch. (2010). An integrated fuzzy approach for the selection of outsourcing manufacturing partners in pharmaceutical R\&D. International Journal of Production Research 48(24): 7483-7506.

Chen, M.Sh., Lin, M.Ch., Wang, Ch.Ch., Chang, C.A. (2009). Using HCA and TOPSIS approaches in personal digital assistant menu-icon interface design. International Journal of Industrial Ergonomics 39(5): 689-702.

Chen, T.Y., Tsao, Ch.Y. (2008). The interval-valued fuzzy TOPSIS method and experimental analysis. Fuzzy Sets and Systems 159(11): 1410-1428. 
Chen, Ch.T., Lin, Ch.T., Huang, S.F. (2006). A fuzzy approach for supplier evaluation and selection in supply chain management. International Journal of Production Economics 102(2): 289-301.

Cheng, C.H. (1996). Evaluating naval tactical missile systems by fuzzy AHP based on the grade value of membership function. European Journal of Operational Research 96: 343-350.

Dağdeviren, M., Yüksel, İ., Kılınç, N. (2009). Weapon selection using the AHP and TOPSIS methods under fuzzy environment. Expert Systems with Applications 36(4): 8143-8151.

Dağdeviren, M., Yüksel, i. (2008). Developing a fuzzy analytic hierarchy process (AHP) model for behavior-based safety management. Information Sciences 178: 1717-1733.

Ding J. F. (2005). Using fuzzy MCDM to select partners of strategic alliances for liner shipping. Information Sciences 173(1-3): 197-225.

Fouladgar, M. M., Yazdani-Chamzini, A., Zavadskas, E. K. (2012). Risk evaluation of tunneling projects. Archives of Civil and Mechanical Engineering 12(1): 1-12.

Fouladgar, M. M., Yazdani-Chamzini, A., Lashgari, A., Zavadskas, E.K., Turskis, Z. (2012). Maintenance strategy selection using AHP and COPRAS under fuzzy environment. International Journal of Strategic Property Management 16(1): 85-104.

Fouladgar, M. M., Yazdani-Chamzini, A., Zavadskas, E. K. (2011). An integrated model for prioritizing strategies of the Iranian mining sector. Technological and Economic Development of Economy 17(3): 459-483.

Fu, G.L., Yang, C., Tzeng, G.H. (2007). A multicriteria analysis on the strategies to open Taiwan's mobile virtual network operators services. International Journal of Information Technology \&Decision Making 6(1): 85-112.

Gamberini, R., Grassi, A., Rimini, B. (2006). A new multi-objective heuristic algorithm for solving the stochastic assembly line re-balancing problem. International Journal of Production Economics 102(2): 226-243.

Gilg, H.A., Boni, M., Balassone, G., Allen, C.R., Banks, D., Moore, F. (2005). Marble-hosted sulfide ores in the Angouran $\mathrm{Zn}-(\mathrm{Pb}-\mathrm{Ag})$ deposit, NW Iran: interaction of sedimentary brines with a metamorphic core complex. Miner Depos 31(1):1-16

Han, Z., Liu, P. (2011). A fuzzy multi-attribute decision-making method under risk with unknown attribute weights. Technological and Economic Development of Economy 17(2): 246-258.

Hartman, H.L. (1992). Introduction to Mining. SME Mining Engineering Handbook (2nd Edition), Society for Mining, Metallurgy, and Exploration, Inc. Littleton, Colorado, pp. 1-4.

Hartman, H.L. (1987). Introductory Mining Engineering. John Wiley, New Jersey.

Huang, J.H., Peng, K.H. (2011). Fuzzy Rasch model in TOPSIS: A new approach for generating fuzzy numbers to assess the competitiveness of the tourism industries in Asian countries. Tourism Management 33: 465-465.

Hwang, C. L., \& Yoon, K. (1981). Multiple attributes decision making methods and applications. Berlin: Springer.

i̇ç, Y. T., Yurdakul, M. (2009). Development of a decision support system for machining center selection.Expert Systems with Applications 36(2) Part 2, 3505-3513.

Kabak, M., Burmaoğlu, S., Kazançoğlu, Y. (2012). A fuzzy hybrid MCDM approach for professional selection. Expert Systems with Applications 39(3): 3516-3525.

Kahraman, C., Cebeci, U., Ruan, D. (2004). Multi-attributi comparison of catering service companies using fuzzy AHP: The case of Turkey. International Journal of Production Economics 87: 171-84.

Kara, S S. (2011). Supplier selection with an integrated methodology in unknown environment. Expert Systems with Applications 38(3): 2133-2139.

KarimiAzari, A.R., Mousavi, N., Mousavi, S. F., Hosseini, S.B. (2011). Risk assessment model selection in construction industry. Expert Systems with Applications 38(8): 9105-9111. 
Kelemenis, A., Ergazakis, K., Askounis, D. (2011). Support managers' selection using an extension of fuzzy TOPSIS. Expert Systems with Applications 38: 2774-2782.

Kung, J., Chuang, T., Ky, C.M. (2011). A fuzzy MCDM method to select the best company based on financial report analysis. In IEEE international conference on fuzzy systems, 2013-2017

Kutlu, A.C., Ekmekçioğlu, M. (2012). Fuzzy failure modes and effects analysis by using fuzzy TOPSIS-based fuzzy AHP. Expert Systems with Applications 39(1): 61-67.

Lashgari, A., Yazdani-Chamzini, A., Fouladgar, M.M., Zavadskas, E.K., Shafiee, S., Abbate, N. (2012). Equipment selection using Fuzzy Multi Criteria Decision Making model: Key study of Gole Gohar Iron Min. Inzinerine Ekonomika- Engineering Economics 23(2): 125-136.

Lashgari, A., Fouladgar, M.M., Yazdani-Chamzini, A., Skibniewski, M.J. (2011). Using an integrated model for shaft sinking method selection. Journal of Civil Engineering and Management 17(4): 569-580.

Laubscher, D.H. (1981). Selection of Mass Underground Mining Methods. Design and Operation of Caving and Sublevel Stoping Mines. SME-AIME, New York.

Leeneer, I., Pastijn, H. 2002. Selecting land mine detection strategies by means of outranking MCDM techniques. European Journal of Operational Research 139(2): 327-338.

Li, D. F. (2007). Compromise ratio method for fuzzy multi-attribute group decision making. Applied Soft Computing 7(3): 807-817.

Miller-Tait, L., Panalkis, R., Poulin, R. (1995). UBC mining method selection. In: Proceeding of the Mine Planning and Equipment Selection Symposium, 163-168.

Mikaeil, R., Naghadehi, M. Z., Ataei, M., KhaloKakaie, R. (2009). A Decision Support System Using Fuzzy Analytical Hierarchy Process (FAHP) and TOPSIS Approaches for Selection of the Optimum Underground Mining Method. Archives of Mining Sciences 54 (2): 341-368.

Montazeri, M., Owlia, M.S., Moghimi, A., Kamalzadeh, M. (2011). Optimal selection of location for Distributed Generations to ensure a competitive advantage using fuzzy analytical network process. IEEE International Conference on Industrial Engineering and Engineering Management, pp. 544-548.

Morrison, R.G.K. (1976). AW Philosophy of Ground Control. McGill University, Montreal, Canada.

Musingwini, C. (2010). Techno-Economic Optimization of Level and Raise Spacing In Bushveld Complex Platinum Reef Conventional Breast Mining. Journal of South African Institute of Mining and Metallurgy 110(8): 425-436.

Naghadehi, Z. M., Mikaeil, R., Ataei, M. (2009). The Application of Fuzzy analytic Hierarchy Process (FAHP) Approach to Selection of Optimum Underground Mining Method for Jajarm Bauxite Mine, Iran, Expert Systems with Applications 36(4): 8218-8226.

Namin, F. S., Shahriar, K., Bascetin, A., Ghodsypour, S. H. (2009). Practical applications from decision-making techniques for selection of suitable mining method in Iran, Mineral Resources Management - Gospodarka Surowcami Mineralnymi 25(3): 57-77.

Nicholas, D.E. (1981). Method Selection - A Numerical Approach. Design and Operation of Caving and Sublevel Stoping Mines. SME-AIME, New York.

Owusu-Mensah, F., Musingwini, C. (2011). Evaluation of ore transport options from Kwesi Mensah Shaft to the mill at the Obuasi mine. International Journal of Mining, Reclamation and Environment 25(2): 109-125.

Önüt, S.; Soner, S. (2008). Transshipment site selection using the AHP and TOPSIS approaches under fuzzy environment. Waste Management 28(9): 1552-1559.

Önüt, S. (2010). Combined fuzzy MCDM approach for selecting shopping center site: An example from Istanbul, Turkey. Expert Systems with Applications 37(9): 6129-6137.

Paksoy, T., Pehlivan, N.Y., Kahraman, C. (2011). Organizational strategy development in distribution channel management using fuzzy AHP and hierarchical fuzzy TOPSIS. Expert Systems with Applications 39(3): 2822-2841. 
Parkan, C., Wu, M.L. (1999). Decision-making and performance measurement models with applications to robot selection. Computers \& Industrial Engineering 36(3): 503-523.

Rostamzadeh, R., Sofian, S. (2011). Prioritizing effective 7Ms to improve production systems performance using fuzzy AHP and fuzzy TOPSIS (case study), Expert Systems with Applications 38(5): 5166-5177.

Saaty, T.L. (1980). The Analytic Hierarchy Process. McGraw-Hill, Pittsburgh.

Sadi-Nezhad, S., Damghani, K. Kh. (2010). Application of a fuzzy TOPSIS method base on modified preference ratio and fuzzy distance measurement in assessment of traffic police centers performance. Applied Soft Computing 10(4): 1028-1039.

Singh, R.K., Benyoucef, L. (2011). A fuzzy TOPSIS based approach for e-sourcing. Engineering Applications of Artificial Intelligence 24: 437-448.

Sun, Ch. Ch. (2010). A performance evaluation model by integrating fuzzy AHP and fuzzy TOPSIS methods. Expert Systems with Applications 37(12): 7745-7754.

Sun, Ch. Ch.; Lin, G. T. R. (2009). Using fuzzy TOPSIS method for evaluating the competitive advantages of shopping websites. Expert Systems with Applications 36(9): 11764-11771.

Torfi, F., Farahani, R. Z., Rezapour, Sh., (2010). Fuzzy AHP to determine the relative weights of evaluation criteria and Fuzzy TOPSIS to rank the alternatives. Applied Soft Computing 10(2): 520-528.

Tzeng, M.L. (2011). Using hybrid MCDM to evaluate the service quality expectation in linguistic preference. Applied Soft Computing 11(8): 4551-4562.

Tupenaite, L., Zavadskas, E.K., Kaklauskas, A., Turskis, Z., Seniut, M., (2010). Multiple criteria assessment of alternatives for built and human environment renovation. Journal of Civil Engineering and Management 16(2): 257-266.

Van Laarhoven, P.J.M., Pedrycz, W. (1983). A fuzzy extension of Saaty's priority theory. Fuzzy Sets and Systems 11: 229-241.

Wang, J.W, Cheng, Ch.H., Huang, K.Ch. (2009). Fuzzy hierarchical TOPSIS for supplier selection. Applied Soft Computing 9(1): 377-386.

Wang, Y.M., Elhag, T.M.S. (2006). Fuzzy TOPSIS method based on alpha level sets with an application to bridge risk assessment. Expert Systems with Applications31(2): 309-319.

Yazdani-Chamzini, A.; Yakhchali, S. H. (2012a). Handling equipment Selection in open pit mines by using an integrated model based on group decision making, International Journal of Industrial Engineering Computations 30: 194-204.

Yazdani-Chamzini, A.; Yakhchali, S. H. (2012b). Tunnel Boring Machine (TBM) selection using fuzzy multicriteria decision making methods. Tunnelling and Underground Space Technology 30: 194-204.

Yong, D. (2006). Plant location selection based on fuzzy TOPSIS. The International Journal of Advanced Manufacturing Technology 28(7-8): 839-844.

Yu, X., Guo, Sh., Guo, J., Huang, X. (2011). Rank B2C e-commerce websites in e-alliance based on AHP and fuzzy TOPSIS. Expert Systems with Applications 38 (4): 3550-3557.

Yu, L., Shen, X., Pan, Y., Wu, Y. (2009). Scholarly journal evaluation based on panel data analysis. Journal of Informetrics 3(4): 312-320.

Zadeh, L.A. (1965). Fuzzy sets. Information and Control 8 (3): 338-353.

Zandi, F., Tavana, M. (2011). An Optimal Investment Scheduling Framework for Intelligent Transportation Systems Architecture. Journal of Intelligent Transportation Systems 15(3): 115-132.

Zouggari, A., Benyoucef, L. (2012). Simulation based fuzzy TOPSIS approach for group multicriteria supplier selection problem, Engineering Applications of Artificial Intelligence 25(3): 507-519. 


\section{KORIŠTENJE INTEGRIRANOG MCDM MODELA ZA ODABIR TEHNIKE RUDARENJA U SLUČAJU NESIGURNOSTI}

Sažetak: Cilj ovog rada je izvođenje efikasnog i primjenjivog modela odabira najbolje proizvodne tehnike na primjeru Angouran rudnika koji je jedan od glavnih proizvođača cinka u Iranu. Proizvodne tehnike ekstrakcije ruda su izravno ili neizravno ovisne o izboru tehnika izvlačenja ruda, jednog od najkritičnijih pitanja u odlučivanju u fazi projektiranja rudnika koji bi trebao biti izrađen. Broj evaluacijskih kriterija često su u sukobu jedni s drugima pri odabiru i ocjeni prihvatljive proizvodne (rudarske) metode $\mathrm{i}$ tehnike. Dakle, problem odabira prihvatljive proizvodne rudarske metode u praksi je problem odabira multi-kriterijskog odlučivanja (MCDM). $S$ druge strane, s obzirom na složenost i strukturu problema, nepreciznih podataka, manjkavost informacija, a time i inherentnu nesigurnost, korištenje fuzzy tehnika može biti od iznimne koristi. $U$ ovom radu integrirani model koji se temelji fuzzy analitičkoj hijerarhiji procesa (FAHP) i fuzzy tehnikama za redom preferencija po sličnosti idealnog rješenja (FTOPSIS) je razvijen i prezentiran. FAHP se primjenjuje za određivanje relativne težine kriterija za ocjenu najbolje proizvodne tehnike pri ekstrakciji ruda u odnosu na ostale dostupne alternativne proizvodne tehnike. Rezultati istraživanja rada testirani su analizom osjetljivosti rezultata. Rezultati ovog istraživanja pokazuju učinkovitost, sposobnost i robusnost predloženog modela izbora proizvodnih tehnika, koji se mogu primijeniti na različite vrste složenih problema u stvarnom životu.

Ključne riječi: Odabir metode rudarstva, MCDM, FTOPSIS, FAHP, grupno odlučivanje 